University of Nebraska - Lincoln

DigitalCommons@University of Nebraska - Lincoln

$5-2000$

\title{
Parent Brine of the Castile Evaporites (Upper Permian), Texas and New Mexico
}

Walter E. Dean

U.S. Geological Survey, Denver, CO, dean@usgs.gov

Douglas W. Kirkland

Department of Geosciences, The University of Texas at Dallas, Richardson, Texas 75288, U.S.A.

Rodger E. Denison

Department of Geosciences, The University of Texas at Dallas, Richardson, Texas 75288, U.S.A.

Follow this and additional works at: https://digitalcommons.unl.edu/usgsstaffpub

Part of the Earth Sciences Commons

Dean, Walter E.; Kirkland, Douglas W.; and Denison, Rodger E., "Parent Brine of the Castile Evaporites (Upper Permian), Texas and New Mexico" (2000). USGS Staff -- Published Research. 307.

https://digitalcommons.unl.edu/usgsstaffpub/307

This Article is brought to you for free and open access by the US Geological Survey at DigitalCommons@University of Nebraska - Lincoln. It has been accepted for inclusion in USGS Staff -- Published Research by an authorized administrator of DigitalCommons@University of Nebraska - Lincoln. 


\title{
PARENT BRINE OF THE CASTILE EVAPORITES (UPPER PERMIAN), TEXAS AND NEW MEXICO
}

\author{
DOUGLAS W. KIRKLAND, ${ }^{1}$ RODGER E. DENISON,${ }^{1}$ AND WALTER E. DEAN ${ }^{2}$ \\ ${ }^{1}$ Department of Geosciences, The University of Texas at Dallas, Richardson, Texas 75288, U.S.A. \\ e-mail: dougkirk@utdallas.edu \\ ${ }^{2}$ U.S. Geological Survey, Denver, Colorado 80225, U.S.A.
}

\begin{abstract}
The Upper Permian (lower Ochoan) Castile Formation is a major evaporite sequence $\left(\sim 10,000 \mathrm{~km}^{3}\right)$ of calcite, anhydrite, and halite in west Texas and southeastern New Mexico. Traditionally the Castile brine has been considered to have been derived from seawater. This tradition has recently been challenged by two versions of the closed-basin drawdown model. They call for deposition from a mixed brine, in part marine and in large part nonmarine. They propose drawdown of as much as $500 \mathrm{~m}$ to form a major sink for ground water issuing from the surrounding Capitan reef complex. A large fraction of the solute in the brine body is inferred to have been recycled from older Permian evaporites on the surrounding shelf.

Strontium-isotope analyses show no evidence that meteoric ground water was contributed to the Castile brine. From a stratigraphic, geographic, and lithologic array of 65 samples of anhydrite, gypsum, and calcite, 59 have an ${ }^{87} \mathrm{Sr} /{ }^{86} \mathrm{Sr}$ ratio of $0.706923(\Delta \mathrm{sw}$ of -225.0$)$, a ratio that is the same as that of strontium in early Ochoan ocean water. If considerable $(>15 \%)$ influx of meteoric water had occurred, enough continental strontium would have been introduced to have resulted in higher ratios.
\end{abstract}

Low bromide values (20-40 ppm) in Castile halite, which have been used to argue for meteoric influx and for recycled salt, probably resulted from diagenesis. During shallow burial by halite, centimeter-size, bottom-grown crystals of gypsum were altered to nodular anhydrite. The rising water of dehydration caused the halite to recrystallize. During the recrystallization, some bromide was expelled.

Despite the large volume of water that evaporated annually from its surface $\left(\sim 52 \mathrm{~km}^{3} / \mathrm{yr}\right.$, assuming an evaporation rate of $\left.2 \mathrm{~m} / \mathrm{yr}\right)$, the Castile brine body never completely desiccated. The surrounding shelf was flat, hot, and generally dry. It probably could not have supplied a significant volume of meteoric spring water to the basin over tens of thousands of years. More likely, during the entire history of the evaporite sequence, influx was dominantly marine. Marine ground water flowed through the Capitan Formation into the evaporite basin along its southern and possibly western margin probably with a rate of flow that was usually fast enough to prevent major drawdown of the brine surface.

\section{INTRODUCTION}

Castile evaporites are exposed or shallowly buried over a large area of west Texas and southeastern New Mexico (Fig. 1). The evaporites (Upper Permian) represent the early part of the Ochoan stage (Adams et al. 1939). The relationship of the Castile Formation to the immediately older and younger formations with which it is associated is shown in Figure 2. The most distinctive features of the Castile are small-scale, rhythmic alterations of calcite-gypsum, and, in the subsurface, calcite-anhydrite and calciteanhydrite-halite. These alternations record a remarkably detailed meteorological and sedimentological record of Late Permian history (Udden 1924; Anderson 1982). Representative outcrops, continuous cores, and hundreds of boreholes constrain Castile thickness, lithology, and facies distribution, but profound differences in interpretation of its origin remain. We consider here the most fundamental of the ongoing controversies-the origin of the parent brine.

\section{Prelude to the Castile Evaporites}

In late Guadalupian time (Late Permian) during an interval of tectonic quiescence in west Texas and southeastern New Mexico, a deep topographic basin became nearly encircled by the Capitan reef. The reef extended along the margin of the basin for more than $500 \mathrm{~km}$ (e.g., Adams and Frenzel 1950) (Fig. 3A). Reef debris formed slopes up to $35^{\circ}$ (King 1947; Scholle et al. 1992), and the reef front had slopes approaching the vertical (B.L. Kirkland et al. 1993) (Fig. 3B). Seawater is traditionally thought to have entered the basin through a southern gap in the reef, the Hovey channel (Fig. 3A); however, the evidence is ambiguous, and a southwestern channel is possible (Hill 1999). The average depth of seawater in the sediment-starved basin was about $500 \mathrm{~m}$ (e.g., Newell et al. 1953, p. 190). Landward from the reef was a wide shelf-facies complex of tidal, lagoonal, and sabkha environments. Here the depth of seawater was seldom more than a few meters (Fig. 3B). Carbonates accumulated directly shelfward from the reef, evaporites and redbeds accumulated farther shelfward, and redbeds accumulated in the hinterland (Fig. 3A).

In latest Guadalupian time, shortly before Castile deposition, the channel (or channels) through which seawater entered the basin became restricted. This restriction may have occurred when the Capitan reef and reef debris protruded into the channel (Ross 1986; Garber et al. 1989) or when the channel became narrower and shallower because of a fall in sea level (Forney 1975; Ross and Ross 1987). Because of the restriction, because the climate was arid (Kutzbach and Gallimore 1989; Scholle et al. 1992; Parrish 1995), and because riverine water was absent, there was a progressive increase in the salinity of the basinal and shelfal marine water.

\section{Castile Evaporites}

By the beginning of Ochoan time the reef and shelf were probably emergent (Oriel et al. 1967; Melim and Scholle 1989; S.U. Noé, personal communication 1998). In the basin the salinity of surface water increased until it was several times greater than that of Permian seawater. Evaporitic precipitation began, and a thin (tens of centimeters) bed of laminated, siltpoor, aragonitic mud-the initial Castile evaporite-accumulated on the basin floor. This bed was the harbinger of the thick sequence of calcium carbonate, calcium sulfate, and sodium chloride that accumulated during the rest of Castile time (Anderson et al. 1972).

The Castile Formation originally underlay at least $25,900 \mathrm{~km}^{2}$, and had a maximum thickness of about $640 \mathrm{~m}$ and an original volume exceeding $10,000 \mathrm{~km}^{3}$ (Adams 1944; King 1947; Snider 1966). The formation originally consisted, by volume, of about $5 \%$ calcite, $45 \%$ anhydrite, and $50 \%$ halite (Anderson 1981), but Tertiary ground water, chiefly along the western side of the basin, dissolved about half the halite. Siliciclastics are almost absent. The Castile Formation is subdivided into a Basal Limestone Member, four anhydrite members, I-IV (from oldest to youngest), and three intervening halite members, I-III (from oldest to youngest) (Anderson et al. 1972).

The evaporite basin was probably situated between 5 and $10^{\circ} \mathrm{N}$ latitude (Scotese 1994; Golonka et al. 1994) on the western margin of Pangea adjacent to the huge Panthalassa Ocean. A monsoonal circulation, possibly analogous to that of equatorial east Africa today, led to aridity, high temperatures, and high evaporation rates (Parrish et al. 1986; Kutzbach and Gallimore 1989). The seasonal range in temperature was probably less than $5^{\circ} \mathrm{C}$ (Crowley et al. 1989, their fig. 2). 


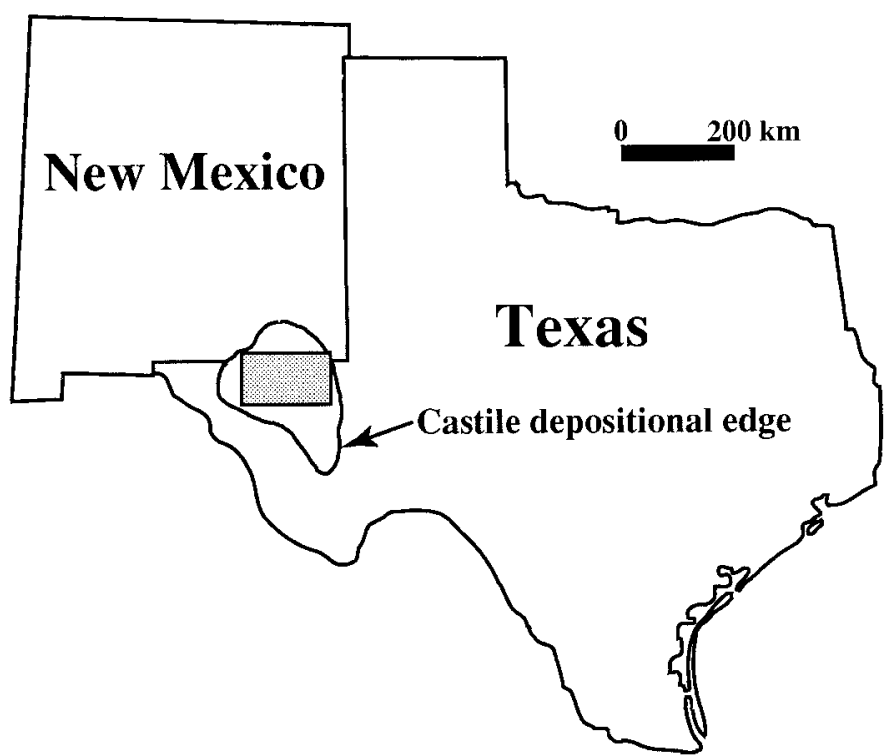

FIG. 1.-Location of Castile depositional basin. Shaded rectangle is the location of map shown in Figure 6.

The Castile is conspicuously cyclic, with each cycle recording progressively increasing salinity of the surface brine. The two most prominent cyclic units are termed "varves"-laminae (or laminae and thin beds) with a period of one year (Udden 1924), and "millennial cycles" — beds with a period of several thousand years (Dean and Anderson 1978).

The most common Castile varve type consists of a couplet-a lamina of calcite (containing organic matter) and a superjacent lamina of anhydrite (Figs. 4A, 5A). Such varves typically have a thickness of about $1.8 \mathrm{~mm}$, with the lamina of calcite forming about $6 \%$ of this value. The varves are generally remarkably regular in thickness, and are commonly repeated thousands of times without interruption. The evaporitic sediments that formed the anhydrite-calcite couplets were cumulates. They formed at the brine surface or in the upper part of the brine and "rained" onto the basin floor. The varves have great lateral persistence, and, as we will show, the thicknesses of individual varves generally remain about the same over most

\begin{tabular}{|c|c|c|c|}
\hline STAGE & SHELF & $\begin{array}{c}\text { SHELF } \\
\text { MARGIN }\end{array}$ & BASIN \\
\hline \multirow{3}{*}{ 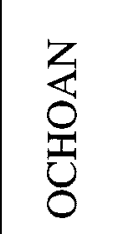 } & Rustler Fm & Rustler Fm & Rustler Fm \\
\hline & Salado Fm & Salado Fm & Salado Fm \\
\hline & & & Castile Fm \\
\hline \multirow{3}{*}{ 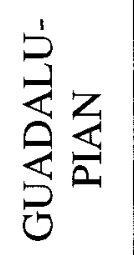 } & Tansill Fm & \multirow{3}{*}{$\begin{array}{l}\text { Capitan } \\
\text { Fm (reef) }\end{array}$} & \\
\hline & Yates Fm & & \\
\hline & $\begin{array}{l}\text { Seven } \\
\text { Rivers Fm }\end{array}$ & & $\sum_{\mathrm{P}} \oplus$ \\
\hline
\end{tabular}

FIG. 2.-Stratigraphic relationship of Castile Formation to associated formations of the shelf, shelf margin, and basin. Vertical lines represent nondeposition. Carbonate tongues from the reef into the basin are: L, Lamar; R, Rader; H, Hegler; and $\mathrm{P}$, Pinery. Formations in bold letters are referred to in text.
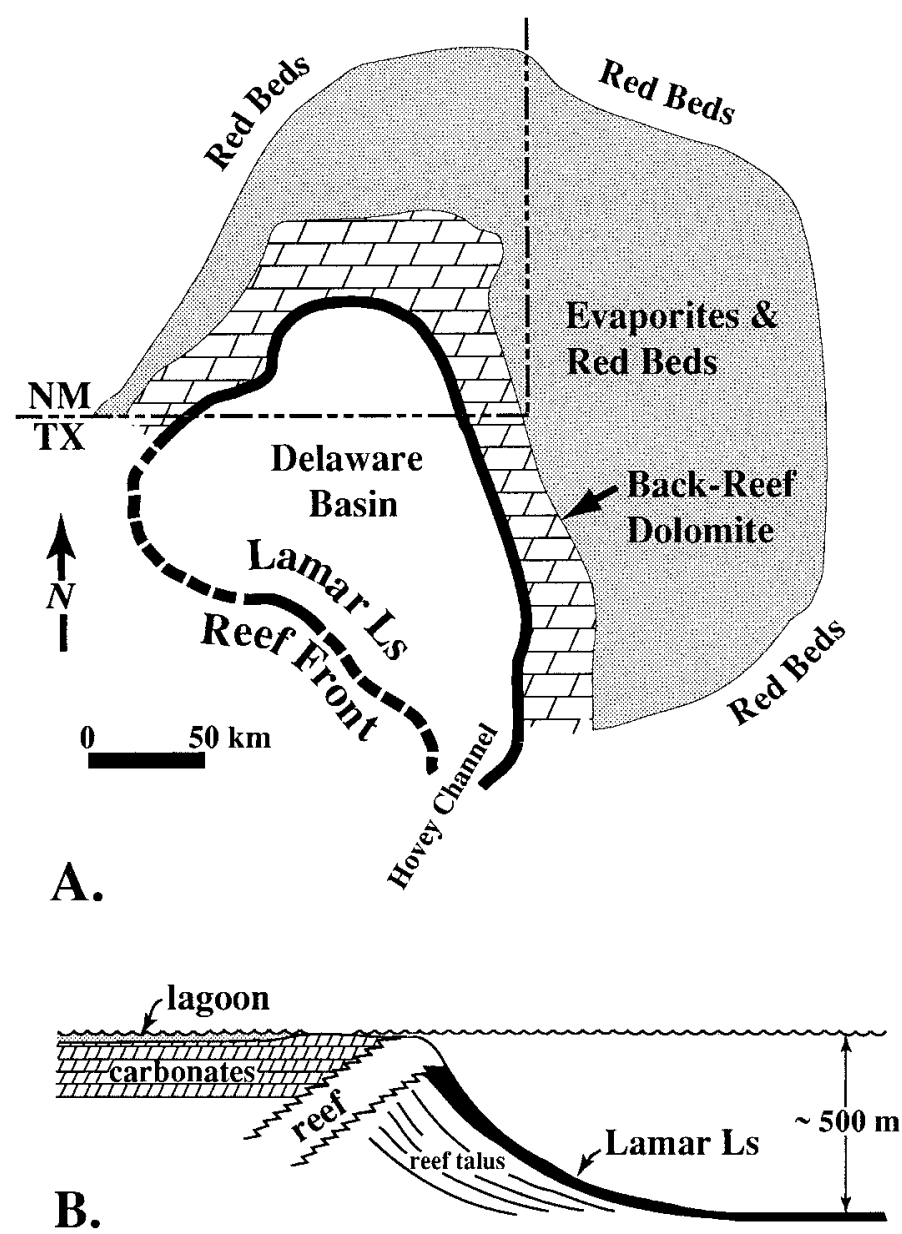

FIG. 3.-A) Late Guadalupian paleogeography shortly before beginning of Castile evaporite deposition (after Ward et al. 1986). Seawater entered the basin through a silled channel or channels traditionally thought to have been the Hovey Channel, as shown. The Capitan reef front is dashed where inferred. From the basin margin, a tongue of limestone, the Lamar, extended for tens of kilometers into the deep basin. Shelfward from the reef, chiefly dolomite of the Tansill Formation accumulated contemporaneously with evaporites and redbeds. B) Cross section showing the relationship and relief of the shelf, basin margin, and basin. This general relationship probably extended almost completely around the basin except at the silled channel (or channels) to the open ocean.

of the basin. On the basis chiefly of thickness variations of anhydrite laminae, cores of alternating laminae of calcite and anhydrite have been correlated definitively over distances of up to $113 \mathrm{~km}$ (e.g., Kirkland and Anderson 1970, their fig. 10b; Dean and Anderson 1982, their figs. 4, 5, 6 , and 7). Most laminae can probably be correlated unequivocally throughout almost the entire basin to within a fraction of a millimeter.

The Castile varve cycle (e.g., Udden 1924; Anderson et al. 1972; Anderson 1982) is difficult to verify. The varve model, however, is supported by geochemical evidence (e.g., Burdett 1985), by deposition of varves in modern salinas (e.g., Kushnir 1981), by the great regularity of these small Castile cycles, and by thicknesses for these small cycles commensurate with deposition from marine water at reasonable annual evaporation rates (King 1947; Dean 1967; Magaritz et al. 1983). Probably only the amplitude of the seasonal climatic change, which is two orders of magnitude greater than for longer periods (Mitchell 1976), would have been great enough to impose the great regularity and prominence of the laminated Castile fabric. Judging from varve counts, the Castile was deposited in 175,000 yr (Anderson 1982).

The second type of prominent cycle, the millennial cycle, occurs 


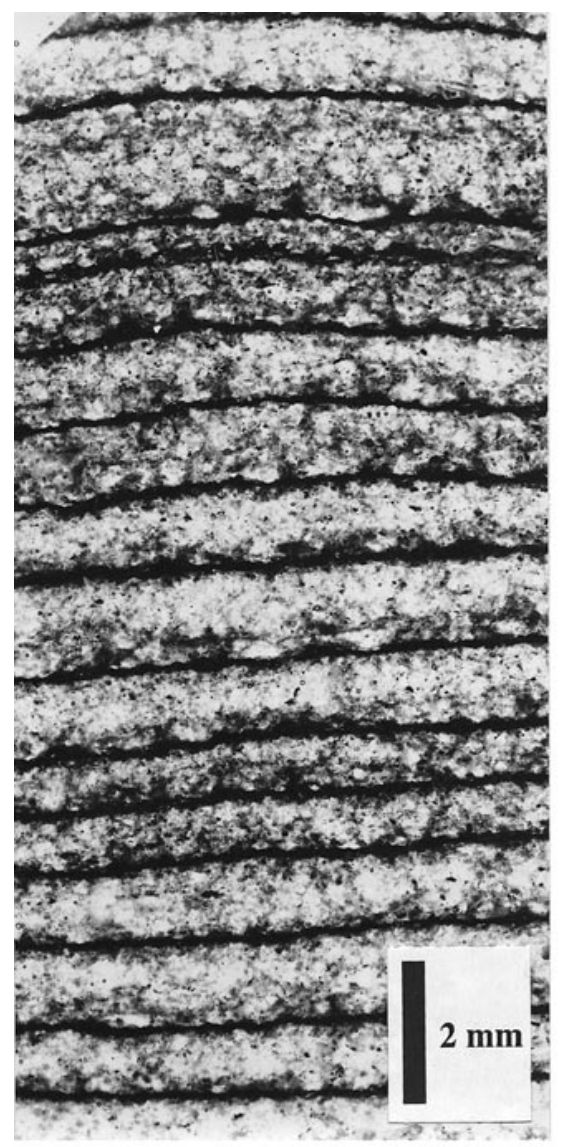

A.

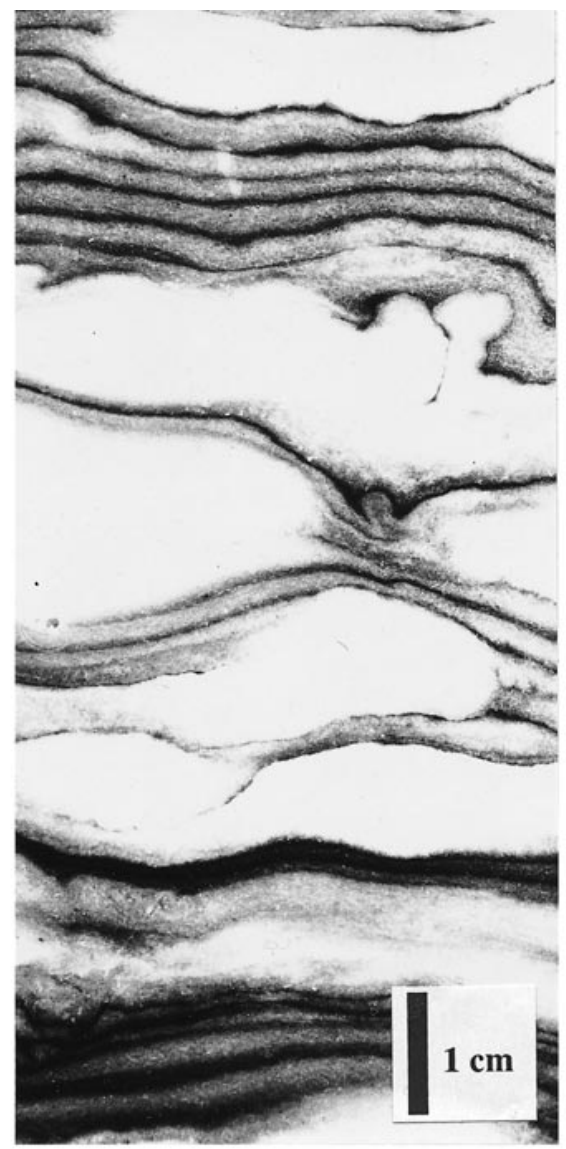

B.

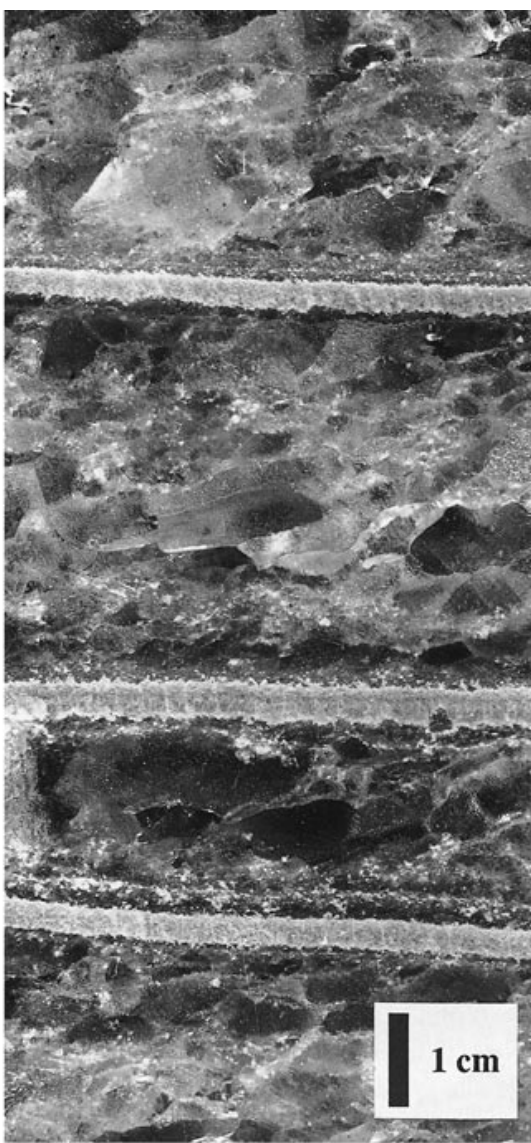

C.

FIG. 4.-Typical Castile lithologies: A) Calcite (dark)-anhydrite (light) couplets, thin section of core, Cowden 2 borehole; B) nodular anhydrite intercalated with calciteanhydrite couplets, polished core slab, UNM-Phillips 1 borehole; C) halite-anhydrite couplets, core slab, Union 4 University 37 borehole. See Figure 6 for locations of boreholes.

throughout the Castile (Dean and Anderson 1978; Anderson and Dean 1995) (Fig. 5B). These cycles generally have a thickness of several meters. On the basis of the varve model, the cycles have an average periodicity of about 2700 yr with a range of 1800-3000 yr (Anderson and Dean 1995). A cycle generally begins with couplets of calcite-anhydrite in which the anhydrite laminae are unusually thin. Calcite may form as much as 80-99 wt \% of these couplets (Anderson and Dean 1995). Above the basal carbonate-rich part, anhydrite laminae increase in thickness, forming the calcite-banded anhydrite typical of the Castile (Fig. 4A). Here calcite constitutes 10-15 wt \% (Dean 1967). Upward within the cycle, anhydrite laminae become even thicker, with calcite laminae constituting about 5 wt \% (Dean and Anderson 1978). Farther upward within these thick anhydrite laminae are nodules of anhydrite (Fig. 4B). Some beds, commonly about $1 \mathrm{~m}$ thick, resemble "chicken-wire anhydrite." Sporadically associated with beds of nodular anhydrite are centimeter-size, anhydrite pseudomorphs of upwardgrowing gypsum crystals (Kendall and Harwood 1988, 1989; Hovorka 1989). In about one in ten cycles, nodular anhydrite is overlain by anhydrite-banded halite (Fig. 4C) (Anderson and Dean 1995); although the contact is abrupt, deposition was regular and uninterrupted. Most of the Castile halite is recrystallized (Anderson et al. 1972).

In cores from the Union 4 University 37 borehole (Fig. 6), Leslie et al. (1996) reported abundant, structureless interbeds of anhydrite up to $10 \mathrm{~m}$ thick that do not exhibit the lamination typical of most Castile anhydrite. In the Anhydrite I Member these beds constitute about $30 \%$ of the total thickness. Leslie et al. (1996) interpreted these beds to be the product of turbidity currents. The beds of resedimented sulfate may have originated in shoals along the eastern margin of the basin. Their insertion into the laminated anhydrite may be largely responsible for the general eastward increase in thickness of the Anhydrite I through III Members (see Anderson et al. 1972, their figs. 10, 14). In cores from the PDB-03 research well, nearer the center of the basin (Fig. 6), "thick turbiditic units" are less common (Leslie et al. 1996). In cores from the Phillips and Cowden boreholes (Fig. 6), turbidite units are unreported, but judging from unpublished photographs (e.g., Dean 1967, his plate 3) they are probably rarely present.

\section{Proposed Depositional Models}

The presumption that the Castile evaporites precipitated from marinederived brine began with Baker (1929), who, because of their great volume and composition, considered them to be marine. Adams (1944) concurred, stating, "This hypothesis is accepted without question".

King (1947) proposed the first widely accepted depositional model for the Castile evaporites. In his model, evaporites precipitated from seawater in a restricted marine embayment that received insignificant "terrestrial water'. The basinal, marine-derived brine was hundreds of meters deep, and the brine level was the same as sea level. To replace water lost by evaporation, seawater flowed into the embayment as a surface current through a silled channel. Concurrently, to account for an anhydrite:halite ratio of about 1:1, instead of an expected ratio of about 1:26, King (1947) 


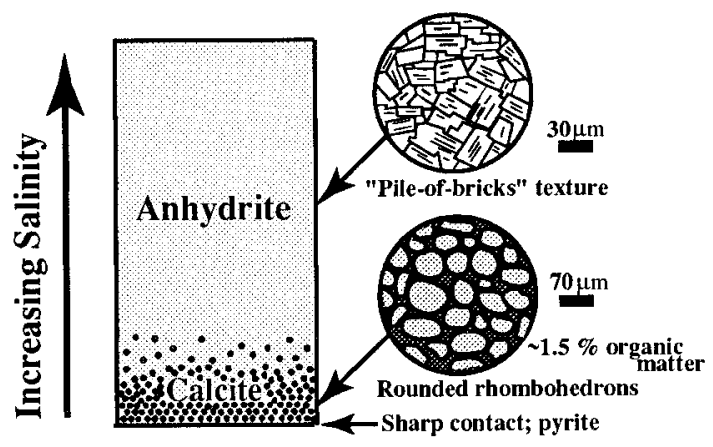

A.

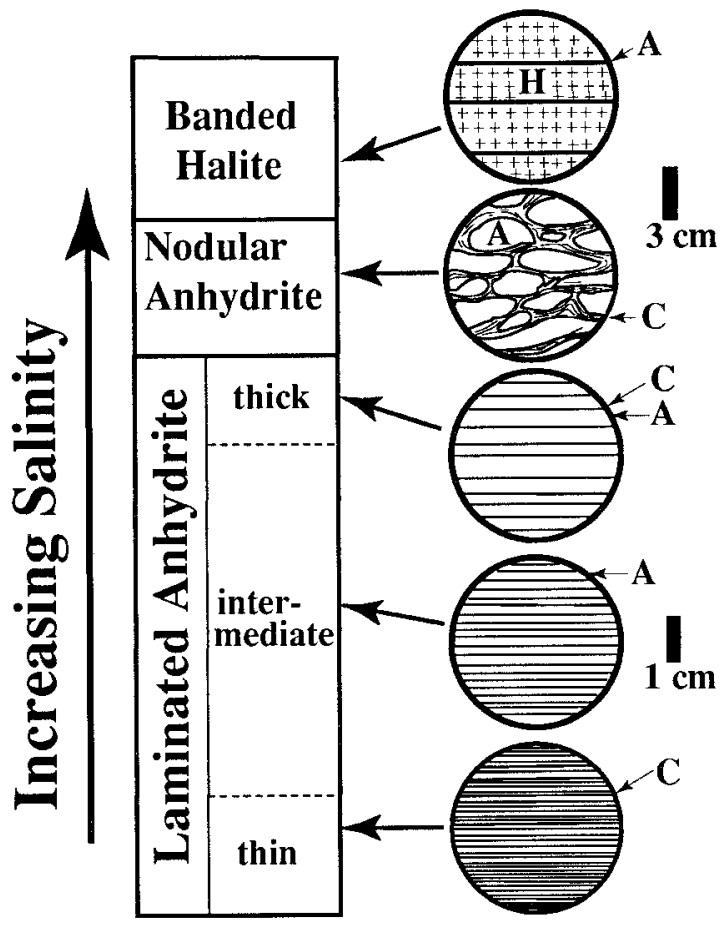

B.

Fig. 5.-Diagrammatic representation of the two most prominent Castile cycles: A) Typical calcite-anhydrite varve cycle; the thickness is typically about $1.8 \mathrm{~mm}$. B) Complete millennial cycle (the banded halite is commonly absent); modified after Dean and Anderson (1978), who indicated that a representative cycle thickness is 4 m; A, anhydrite; $\mathrm{C}$, calcite; $\mathrm{H}$, halite.

proposed that concentrated brine (about $10 \%$ of the influx) flowed out of the basin as a submarine current through the same silled channel.

Lucia (1972) provided the first serious challenge to King's model. Lucia argued that, by analogy with modern silled basins, gypsum could not have precipitated from a Castile marine embayment unless the inlet between the basin and the open sea had a cross-sectional area less than $0.3 \mathrm{~km}^{2}$. In relation to the size of the basin, such a small inlet would have been inconsequential. Halite could not have precipitated unless the basin was completely isolated from the ocean. Lucia visualized the Castile evaporite basin as an "inland sea" - technically a saline lake - rather than a "hypersaline lagoon or a silled basin". In Lucia's model, marine water, rather than entering through a shallow channel, seeped into the basin through a "sediment barrier'".

More recently, on the basis of new evidence and new arguments, two closed-basin depositional models have been proposed for the Castile: one by Kendall and Harwood $(1988,1989)$ and Leslie et al. (1996) (Fig. 7A), the other by Anderson (1993) and Anderson and Dean (1995) (Fig. 7B). These models differ in detail, but both are classes of the closed-basin drawdown model (Maiklem 1971). Both models differ greatly from King's "reflux model", but both have affinity with Lucia's "inland sea" concept. These newly proposed models call for periods of imbalance between the volume of water entering the Castile basin and the volume of water leaving the basin. During drawdown a greater volume of water left by evaporation and reflux (if any) than entered by influx of marine and meteoric water. During these periods of "negative" imbalance the surface of the Castile brine level is visualized as having been drawn down hundreds of meters below sea level and below the crest of the Capitan reef.

These closed-basin drawdown models differ in another important respect from the depositional model of King (1947). Drawdown of the surface of the basinal brine is postulated to have lowered the brine level well below the ground-water table in the bounding reef and reef debris (e.g., Fig. 8). Because of the resulting hydrologic head, the basin would have been a major potential sink for ground water (Kendall 1984), both marine and meteoric. A hybrid brine would have formed. Anderson and Dean (1995) considered the basinal brine to have been composed mainly of continental water. They propose, for example, "a small volume of marine inflow relative to meteoric recharge", and a blend of ions that resulted in gypsum and halite being precipitated in a ratio of about 1:1 without the necessity of reflux. Similarly, Kendall and Harwood (1989) concluded that because of the large hydraulic head caused by drawdown, "more than one-half kilometer", that there would be ". . . a strong(?) possibility that much of the basin influx may have been composed of ground- and formation waters that were derived from surrounding marginal platforms" (Fig. 8).

\section{The Problem}

As we show above, the evaporites have been variously categorized as originating dominantly from marine water, dominantly from nonmarine water, or from a mixture of both marine and nonmarine water. We will try to answer the question, "'marine, nonmarine, or hybrid?' by using isotopic and geologic arguments. Kendall (1988) states " ... there is no more important variable than the type of brine and its origin". For the Castile evaporites a better understanding of the origin of the parent brine would constrain the various genetic models, and could lead to an improved understanding of the depth of the brine body, the origin of the salinity cycles, and the magnitude (even the necessity) of reflux.

In the following sections we estimate the volume of water that the Castile evaporite basin required annually, on average, to prevent desiccation, and consider what this essential volume suggests about the brine. We then review sulfur-isotope analyses of the Castile sulfates and consider their potential for determining the type of parent brine. In a similar consideration, strontium-isotope results for samples of the Castile evaporites are presented and interpreted. We briefly consider other evidence bearing on the parent brine. We then reinterpret the bromide data, which have been used to support influx of large volumes of meteoric water into the evaporite basin. Finally, a depositional model is proposed that involves dominantly marine water.

\section{VOLUME OF REPLACEMENT WATER REQUIRED ANNUALLY}

Because of its confinement, or near confinement, by the Capitan reef, the area of the brine body that occupied the evaporite basin can be esti- 


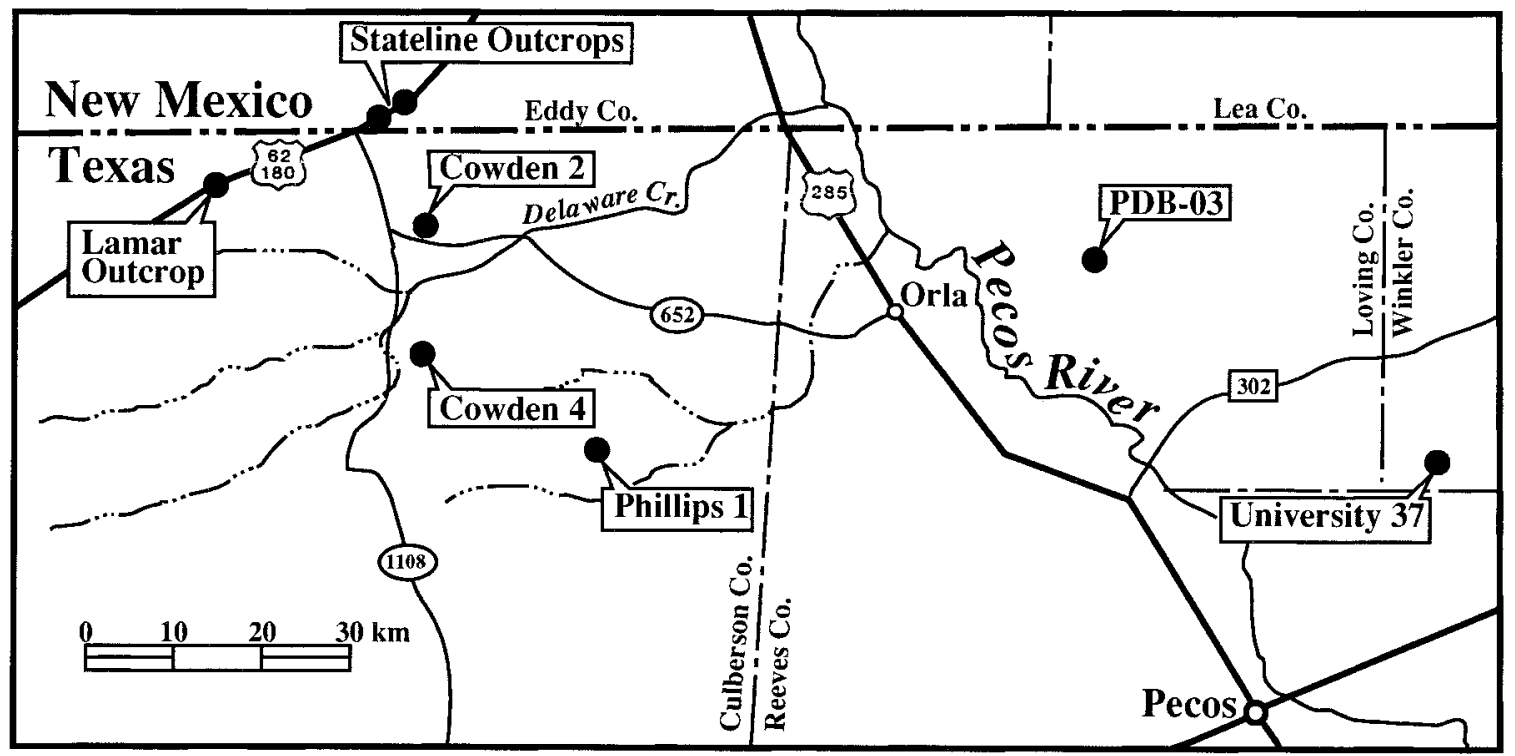

FIG. 6.-Location of boreholes and outcrops referred to in text.

mated with a degree of accuracy unusual for evaporite deposits. We recalculated the surface area of the Castile brine within the bounding reef to be $25,900 \mathrm{~km}^{2}$, the same value determined by King (1947) and by Dean (1967). Because of the steep bounding surface of the basin, substantial drawdown below the crest of the reef could have occurred without appreciably reducing the total basinal area. During parts of its lifespan the Castile brine body may have transgressed over the reef and onto the shelf (S.D. Hovorka, personal communication 1998), the area of the brine body would have exceed $25,900 \mathrm{~km}^{2}$, and the volume of replacement water required annually would have increased proportionally.

We compiled evaporation rates for 15 modern evaporitic environments. They ranged from 1.4 to $5.9 \mathrm{~m} / \mathrm{yr}$, with most values between 1.8 and 3.0 $\mathrm{m} / \mathrm{yr}$. These rates provide a basis for estimating and constraining the rate of evaporation from the Castile brine. Dean (1967, p. 144) estimated the average rate of evaporation from the Castile brine to be $2 \mathrm{~m} / \mathrm{yr}$. This conservative estimate of $2 \mathrm{~m} / \mathrm{yr}$ for the rate of evaporation and 25,900 $\mathrm{km}^{2}$ as the area for the brine surface was used to calculate that $52 \mathrm{~km}^{3}$ of water was lost annually from the Castile brine surface. This volume may have been greater, but it was unlikely to have been smaller.

Evaporation of $2 \mathrm{~m} / \mathrm{yr}$ of modern seawater would result in an anhydrite lamina only $0.85 \mathrm{~mm}$ thick, half as thick as typical Castile anhydrite laminae. Given that the couplets are varves, several variables, individually or in combination, could account for this discrepancy in thickness. First, the concentration of the $\mathrm{Ca}^{2+}$ in the water that influxed into the Castile basin could have been greater than that in modern seawater (409 ppm). The composition of Permian seawater was very similar to that of modern seawater (Horita et al. 1991). We assume that Permian seawater contained about $400 \mathrm{ppm} \mathrm{Ca}^{2+}$, about the same as that of modern seawater; however,

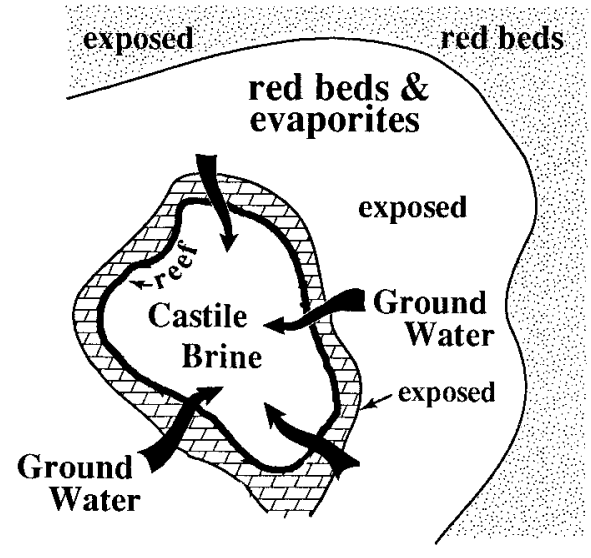

A.

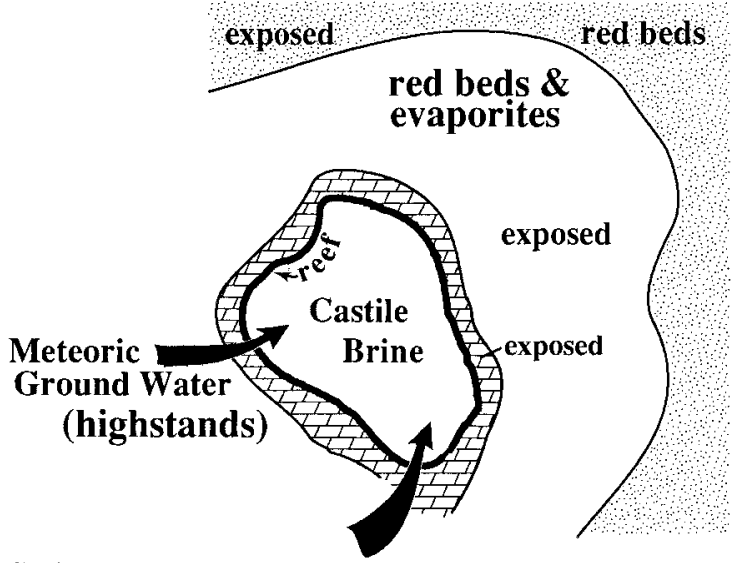

Saline Meteoric Ground Water

or Marine Ground Water

(lowstands)

FIG. 7.-Closed-basin drawdown models for the Castile evaporites: A) model of Kendall and Harwood (after Hill 1996, her fig. 56); B) model of Anderson and Dean (1995) 


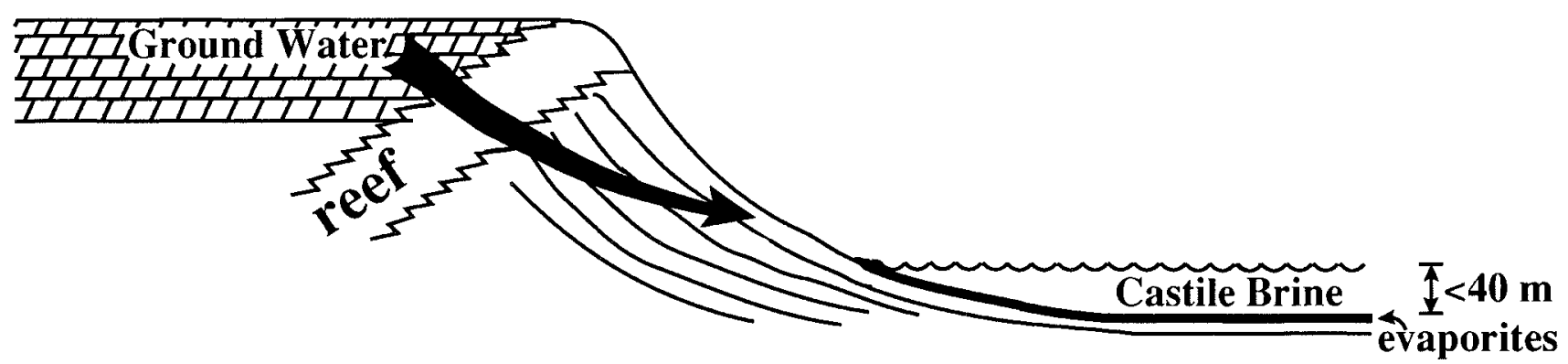

FIG. 8. - Diagrammatic cross section showing closed-basin drawdown model of Kendall and Harwood $(1988$, 1989). Line of section is normal to reef front in Figure 7A. Meteoric ground water might have entered basin around nearly its entire circumference. Depth of Castile brine is not to scale; height from top of reef to floor of basin is about $500 \mathrm{~m}$.

the concentration of $\mathrm{Ca}^{2+}$ in Permian seawater is not well constrained (Horita et al. 1991), and its concentration may have been "somewhat higher" (Timofeef et al. 1998). Secondly, the marine influx could have been preconcentrated in a subsidiary basin, but no data support such a preconcentration. Thirdly, the evaporation rate in the Castile basin could have been $>2 \mathrm{~m} / \mathrm{yr}$. The Castile evaporite basin lay within a band, roughly equatorial, that was arid nearly year-round (Kutzbach and Gallimore 1989, their fig. 5). This aridity, coupled with high year-round temperatures, may have led to evaporation rates well in excess of $2 \mathrm{~m} / \mathrm{yr}$.

Unlike the directly overlying Salado brine body (Lowenstein 1988), the Castile brine body never completely desiccated (Hovorka 1989). Throughout its life, evaporation from the brine surface was essentially continuous. If we assume a lifespan of 175,000 yr for the brine body, an average rate of evaporation of $2 \mathrm{~m} / \mathrm{yr}$, and an area for the brine surface of $25,900 \mathrm{~km}^{2}$, then the total volume of water lost by evaporation during the life of the brine body was $9,065,000 \mathrm{~km}^{3}$. This volume is about 860 times greater than the total volume of brine in the basin at the beginning of evaporite deposition. Loss of brine volume associated with drawdown, therefore, would not have substantially affected the average annual water requirements of the basin.

The approximate equilibrium between water lost and water gained is supported by the great regularity in thickness of calcite-anhydrite couplets. Each couplet probably represents an influx of outside water (whether marine, nonmarine, or a mixture) that contained a new increment of $\mathrm{Ca}^{2+}$, $\mathrm{SO}_{4}{ }^{2-}$, and $\mathrm{HCO}_{3}{ }^{-}$ions. The volume of reflux probably approximately equaled the volume of rainfall onto the brine surface, and, because reflux increased and rainfall decreased the annual water requirements, they were offsetting. Therefore, the estimated volume of water lost annually from the basin by evaporation and reflux, $52 \mathrm{~km}^{3}$, would, on average, have probably been about the same as the volume of water brought into the basin annually by rainfall and influx. This volume was equal to about $30 \%$ of the average annual discharge of the Columbia River (Showers 1979, p. 82).

Siliciclastics, as mentioned above, are virtually absent, yet the basin was surrounded by a watershed containing siliciclastics (Fig. 3A). Thus, rivers could not have contributed significant amounts of water or salts to the Castile basin, as Magaritz (1987) has suggested for other major evaporite basins. Also, because of the absence of siliciclastics, storm runoff was probably insignificant. Other than rainfall, the only significant volume of meteoric water that might have entered the Castile basin was ground water seeping through the Capitan reef and reef debris.

Assume that, on average, meteoric ground water annually contributed $25 \%$ of the estimated $52 \mathrm{~km}^{3}$ of "replacement water". Then for tens of thousands of years an average of about $13 \mathrm{~km}^{3}$ of meteoric ground water moved from the shelf through the Capitan Formation and into the basin. That this much "spring water" originated annually on a hot, dry, or usually dry, exceedingly flat shelf over tens of thousands of years seems improbable. More reasonably, the replacement water was almost entirely seawater.

\section{SULFUR ISOTOPES}

We compiled 36 sulfur-isotope analyses of Castile anhydrite from Claypool et al. (1980), Magaritz et al. (1983), Hill (1996, p. 449), and Leslie et al. (1997). Except for the Basal Limestone, each member of the Castile is represented. The weighted mean of the entire set of $\delta^{34} S$ values is $+11.6 \%$; the variance is very low (standard deviation, 0.15 ) and the range is +11.3 to $+12.0 \%$. The total volume of pyrite that formed within the Castile evaporitic sediment (Anderson and Kirkland 1966; Dean 1967; Burdett 1985) was so small in relation to the total volume of anhydrite that its effect on the $\delta^{34} \mathrm{~S}$ of the Castile anhydrite was insignificant.

The mean $\delta^{34} \mathrm{~S}$ of the Castile sulfate samples $(+11.6 \%$ ) coincides with the $\delta^{34} \mathrm{~S}$ of sulfate in seawater of Permian time $(+9.5$ to $+12.5 \%$ ) (see data of Holser and Kaplan 1966 and Claypool et al. 1980). This coincidence strongly suggests that the Castile anhydrite was derived from a Permian marine brine. Possibly older Permian marine sulfate beds may have been dissolved by meteoric water, transported in solution in ground water, and reprecipitated in the Castile evaporite basin (Anderson and Dean 1995; Leslie et al. 1996). All known pre-Leonardian marine Phanerozoic sulfates have values of $\delta^{34} \mathrm{~S} \gg 11.6 \%$ (Claypool et al. 1980, their fig. 9). Thus, if an older marine sulfate deposit had been recycled into the Castile basin, the sulfate could only have been of Guadalupian or Leonardian age (or both).

During Castile time, the Tansill Formation, the youngest Guadalupian unit restricted to the shelf (Figs. 2, 3), was the unit most susceptible to erosion. If the Castile anhydrite was largely recycled, the Tansill gypsum facies would probably have been the chief source of the necessary $\mathrm{Ca}^{2+}$ and $\mathrm{SO}_{4}{ }^{2-}$ ions. Sulfate strata of the Tansill covered a wide area (Fig. 3), although their cumulative thickness was much less than that of sulfate strata of the Castile. S.U. Noé (personal communication, 1998) reports karstification and other erosional features at the top of the Tansill, and Melim and Scholle (1989) report that Capitanian strata underwent significant subaerial alteration between the end of Guadalupian carbonate sedimentation and the onlap of Salado evaporitic sediments. On the basis solely of the sulfurisotope data and the evidence of erosion, we are unable to preclude the possibility that a significant fraction of the Castile anhydrite is second cycle.

\section{STRONTIUM ISOTOPES}

Our method of preparing and analyzing samples for strontium-isotope analyses is given in Denison et al. (1998). The strontium standard used for most samples was NBS 987 , for which a ${ }^{87} \mathrm{Sr} /{ }^{86} \mathrm{Sr}$ of 0.710240 was used. We report strontium-isotope values using the $\Delta$ sw notation (the isotopic ratio is given in parentheses); $\Delta$ sw values are obtained by the following equation:

$$
\Delta \mathrm{sW}=\left({ }^{87} \mathrm{Sr} /{ }^{86} \mathrm{Sr}_{\text {unknown sample }}-{ }^{87} \mathrm{Sr} /{ }^{86} \mathrm{Sr}_{\text {seawater }}\right) \times 10^{5}
$$




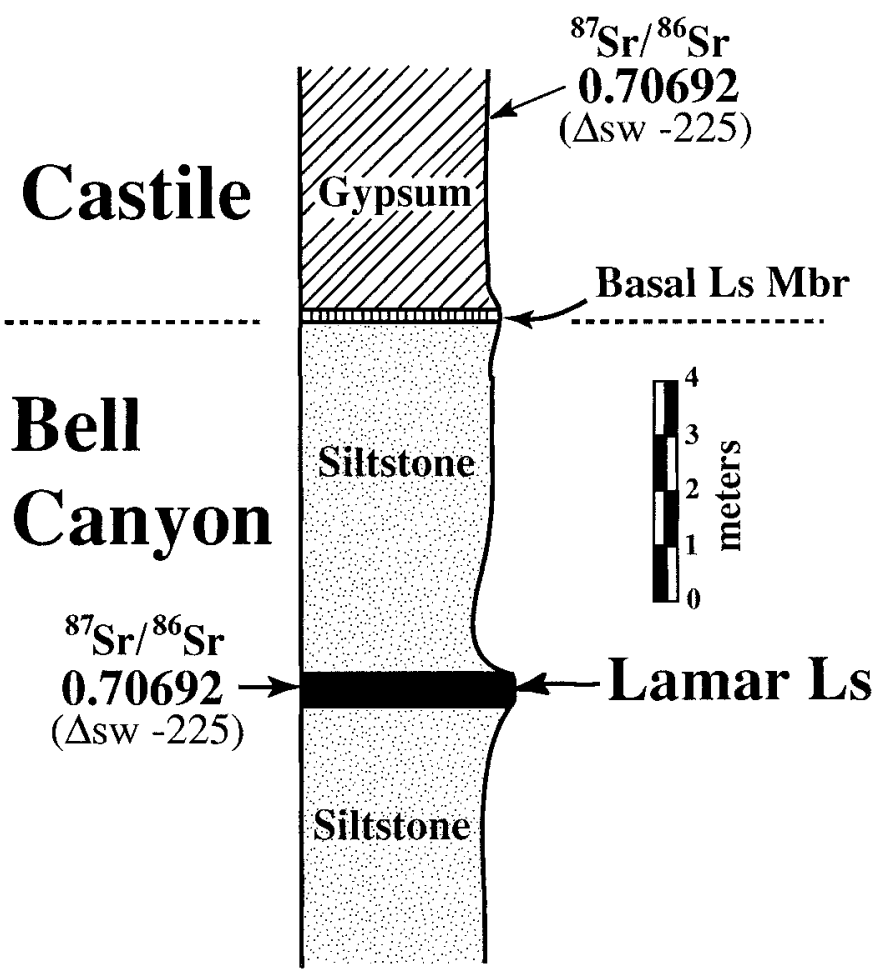

FIG. 9.-Stratigraphic section at the base of the Castile showing the relationship of the Lamar Limestone Member of the Bell Canyon Formation to the Basal Limestone Member of the Castile Formation, showing also that, within analytical error, the isotopic ratio of strontium in the strictly marine Lamar Limestone is the same as that of strontium in gypsum of the Anhydrite I Member of the Castile. The contact of the Castile with the underlying Bell Canyon is conformable.

To determine the mean ${ }^{87} \mathrm{Sr} /{ }^{86} \mathrm{Sr}$ of strontium within modern seawater, $0.709173 \pm 3$, we measured the ${ }^{87} \mathrm{Sr} /{ }^{86} \mathrm{Sr}$ of more than 100 samples of modern shells and modern seawater. The $\Delta$ sw for the NBS standard, therefore, is $+106.7 \pm 0.3\left[(0.710240-0.709173) \times 10^{5}\right]$. Our determined $\Delta$ sw differences between the NBS 987 standard and the strontium in modern seawater compare well with those determined by other workers (see compilation by McArthur 1995).

Using strontium isotopes, it is possible to determine the origin of the parent brine of calcium-bearing evaporites (Denison et al. 1998). A marine origin for the parent brine of a particular evaporite unit is indicated by consistent ${ }^{87} \mathrm{Sr} /{ }^{86} \mathrm{Sr}$ values for samples of calcium-bearing minerals from both different horizons and different locations. Gypsum precipitated from hybrid brines is indicated by strontium isotopes that vary geographically and stratigraphically, but with some values approaching the strontium-isotope value of contemporaneous seawater-a value that is known if the age of the sulfate deposit is known. Gypsum precipitated from saline lakes is indicated by strontium isotopes that vary geographically and stratigraphically, but without values that approach the strontium-isotope value of strontium in seawater at the time of deposition of the gypsum.

The strontium-isotope ratio for seawater at any time is determined by analyzing samples of known age, usually limestone containing a rich, marine fauna. The Lamar Limestone Member of the Bell Canyon Formation, which conformably underlies the Castile Formation by several meters (Fig. 9), contains a variety of indigenous marine fossils (e.g., Babcock 1977). We sampled the Lamar from a roadcut on U.S. 62 (Fig. 6). Many determinations of three samples of the lime mudstone yield a mean $\Delta$ sw of $-225.3 \pm 1.1(0.706920)$ with a range $-222.7 \pm 2.2(0.706946)$ to $-227.6 \pm 1.8(0.706897), n=14$. The samples have a low Mn concen- tration $(<43 \mathrm{ppm})$ and a high $\mathrm{Sr}$ concentration $(>1450 \mathrm{ppm})$, showing that they retained the original seawater ratio (see Denison et al. 1994b). This is reinforced by the isotopic agreement among samples and by the observation that Permian samples from the Permian Basin area that show isotopic exchange are driven to higher isotope values (Denison et al. 1994a, their fig. 2). No older Paleozoic rocks yield ratios lower than those from the Lamar. Denison et al. (1998) determined the value for strontium in seawater of early Salado time to be $\Delta \mathrm{sw}-224.6 \pm 1.8(0.706927)$. Because Castile deposition took place over such a short time, the value for early Ochoan (Castile) seawater must be a value between that of the Lamar and that of the Salado, a $\Delta$ sw of -225 (0.70692).

All of the bedded Castile anhydrite and gypsum samples (50) and all of the Castile calcite samples in anhydrite members (6) have a ${ }^{87} \mathrm{Sr} /{ }^{86} \mathrm{Sr}$ ratio of $0.706923(\Delta \mathrm{sw}-225.0 \pm 1.5)$ that is within error of the mean of all results (Appendix 1). We reasoned that samples of anhydrite laminae intercalated with halite might have been most sensitive to influx of meteoric ground water, but six such samples had $\Delta$ sw values within error of -225.0 (0.706923). Castile samples were analyzed from six localities (Fig. 6). We also reasoned that those localities closest to the potential source of meteoric water (the reef complex) would show this influence in the isotope results, but the mean strontium isotopic value from each locality is, within error, $-225.0(0.706923)$

We analyzed eight groups of 1 to 12 correlative anhydrite lamina or laminae using various core combinations among the Cowden 4, Cowden 2, Phillips 1, and University 37 boreholes (Fig. 6). Each correlative lamina or sequence of laminae has a $\Delta \mathrm{sw}$ of $-225.0(0.706923)$ within analytical error. Figure 10 shows correlative core sections in which we measured the isotope ratio of strontium in the anhydrite fraction of two correlative groups of laminae separated by $113 \mathrm{~km}$.

Six samples yielded higher (more continental-like) ratios. They are five samples from the thin $(<1 \mathrm{~m})$ Basal Limestone Member with $\Delta$ sw values ranging between $-183.0(0.707343)$ to $-203.8(0.707135)$, and one anhydrite breccia in the Halite I Member with a $\Delta$ sw of -215.8 (0.707015).

Brookins (1988) analyzed the ${ }^{87} \mathrm{Sr} /{ }^{86} \mathrm{Sr}$ of seven samples of anhydrite from the Castile (see Hovorka 1990, her fig. 5-13, for their geographic location and stratigraphic position). His values, like ours, show little variance. They are, however, about four $\Delta$ sw units less (the ratio is about 0.000040 less) than our values. Unfortunately, Brookins (now deceased) reported an ${ }^{87} \mathrm{Sr} /{ }^{86} \mathrm{Sr}$ neither for the NBS 987 standard nor for seawater. He reported only a ${ }^{87} \mathrm{Sr} /{ }^{86} \mathrm{Sr}$ of $0.708080 \pm 7$ for the Eimer \& Amend strontium carbonate standard, a value significantly higher than that reported by other workers. If Brookins's Castile data are normalized using E\&A and NBS values measured by other workers (e.g., Gao 1990; Jones et al. 1994) then his results are within error of those reported here.

\section{Interpretation of Isotopic Results}

The anhydrite breccia with an anomalously high $\Delta$ sw value formed when Tertiary ground water dissolved Castile halite beds leaving an anhydrite residue. During its consolidation, continental strontium in the ground water probably became incorporated into the matrix. Ground water that dissolved the halite probably contained strontium with a ${ }^{87} \mathrm{Sr} /{ }^{86} \mathrm{Sr}$ value substantially greater than a $\Delta_{\mathrm{sw}}$ value of $-225(0.706923)$. The strontium-isotope ratio of ground water is determined chiefly by the rocks though which it flows. Many modern ground waters probably contain strontium with $\Delta$ sw values like those of strontium in modern river waters, which range from +103 $(0.710203)$ to +293 (0.712103) (Palmer and Edmond 1992). The five samples yielding anomalous results from the thin limestone at the base of the Castile have trace-element concentrations that suggest diagenetic alteration. Ground water from the directly underlying arkosic siltstone (Bell Canyon Formation) probably infiltrated the carbonate bed, causing recrystallization and introducing foreign radiogenic strontium.

Fifty-nine of the Castile ratios (Appendix 1) are in agreement with our 


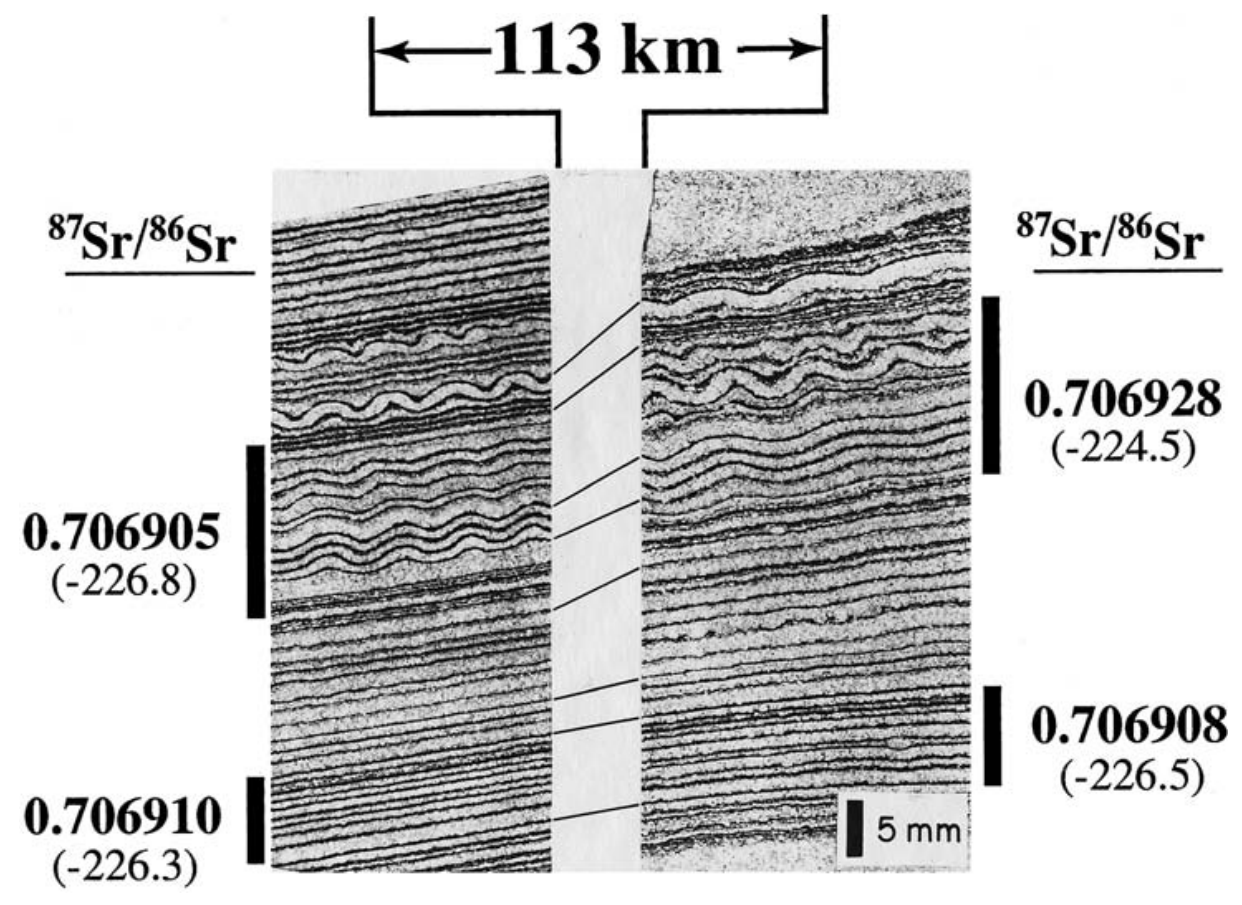

FIG. 10.-Correlative cores from the UNMCowden 4 and the Union 4 University 37 (right) boreholes showing strontium-isotope ratios for an upper group of nine laminae and a lower group of 12 laminae.
${ }^{87} \mathrm{Sr} /{ }^{86} \mathrm{Sr}$ estimate for early Ochoan (Castile) seawater $(0.706923 \pm 15$; $\Delta$ sw $-225.0 \pm 1.5)$. These data are what would be expected for $\mathrm{Ca}-$ bearing minerals that precipitated from a brine formed by evaporation of early Ochoan seawater. We estimate, however, that the Castile marine brine could have consisted of up to about $15 \%$ meteoric ground water without causing the ${ }^{87} \mathrm{Sr} /{ }^{86} \mathrm{Sr}$ ratio to increase outside of analytical error-the "measurable effect" of Bryant et al. (1995). The fraction of meteoric ground water that might have mixed with marine water without being detectable depends on the isotopic ratio and concentration of strontium in both the meteoric and the marine water.

The strontium dissolved in Ochoan meteoric ground water would have been more radiogenic than that in Ochoan seawater $(\Delta \mathrm{sw}-225)$ because continental strontium from chemical weathering of Guadalupian strata on the wide shelf surrounding the evaporite basin would have been incorporated into the ground water. Strontium would have come chiefly from weathering of dolomitic, siliciclastic, and sulfatic strata. Any radiogenic strontium from shelfal sources would have been contributed to the Castile brine body, and the resulting mixture of strontium isotopes would have been recorded in the precipitated gypsum.

The potential effect of meteoric waters mixing with a marine base can be seen by examining strontium-isotope results for the overlying Salado Formation. Of 29 isotope ratios for Salado anhydrites from a core in Lea County, New Mexico, only ten were within error of the seawater ratio (Denison et al. 1998, their fig. 7). The scatter was large. The highest ratio from the samples of Salado anhydrite is $\Delta \mathrm{sw}=-137$ (0.070780), the lowest value for the meteoric end member. This shows that in the geologic setting for the Salado, which was similar to that of the Castile, the continental contribution contained strontium that was much more radiogenic than contemporary seawater.

Aragonitic cement, a major component of the Capitan reef and fore reef (e.g., Schmidt 1977), has been diagenetically altered to low-magnesium calcite and especially to dolomite. During the alteration a considerable volume of excess strontium was released (a Pleistocene analog is reported by Banner et al. 1994). The $\Delta$ sw range of this strontium was like that of Guadalupian seawater $(-195$ to $-225 ; 0.70722$ to 0.70692$)$. If some of this strontium had been released during Castile time, its effect would have been most pronounced on the ${ }^{87} \mathrm{Sr} /{ }^{86} \mathrm{Sr}$ of the Castile brine during low- stands in the basin (during periods of halite deposition), when seepage moved through the older part of the Capitan Formation. The isotopic results from anhydrite intercalated within Castile halite members, however, show no radiogenic influence, and any contribution of strontium from the alteration of Capitan aragonite during Castile time was too small to recognize in our measurements. Most Capitan aragonite was apparently replaced before deposition of the Castile evaporites. Reflux of brines from shelfal Guadalupian lagoons (e.g., Fig. 3) probably resulted in dolomitization of aragonite cement (e.g., Melim 1991), and input of meteoric water during minor Guadalupian oscillations of relative sea level (Garber et al. 1989) probably resulted in periodic calcitization of aragonite cement.

If a significant proportion of the Castile evaporites had been recycled from Guadalupian shelfal evaporites, the dissolved solids in the hypothesized meteoric ground water would have to have been high. If the proportion of dissolved solids had been much less than seawater, an unreasonable rate of evaporation from the brine surface would have been required. The dissolved solids would have been high also because the ground water would have been in contact with Guadalupian sulfate beds, which would have dissolved readily.

In our modeling, we use a concentration for strontium in Late Permian seawater of $8 \mathrm{ppm}$, the same as that in modern seawater, understanding that this value is uncertain. The strontium concentration of Permian seawater is not directly constrained. The $\mathrm{Ca}^{2+} / \mathrm{Sr}^{2+}$ ratio of Permian seawater is, however, likely to have been close to that of modern seawater, and the calcium concentration of Permian seawater probably varied by less than a factor of two from present oceanic values (Holland 1972: Schopf 1980, p. 183). The strontium concentration and isotopic ratio of any meteoric source would have even fewer constraints. Given our analytical precision, the threshold amount of meteoric contribution that cannot be recognized in the isotopic values can be estimated using a simple mixing model (Denison et al. 1998) (Fig. 11). The uncertainties can be evaluated using a suite of meteoric and marine values in the mixing model.

\section{OTHER EVIDENCE BEARING ON TYPE OF PARENT BRINE}

The mean strontium concentration of 60 samples of laminated anhydrite from the Anhydrite I Member (Cowden 2 core) is 2404 ppm, with a stan- 


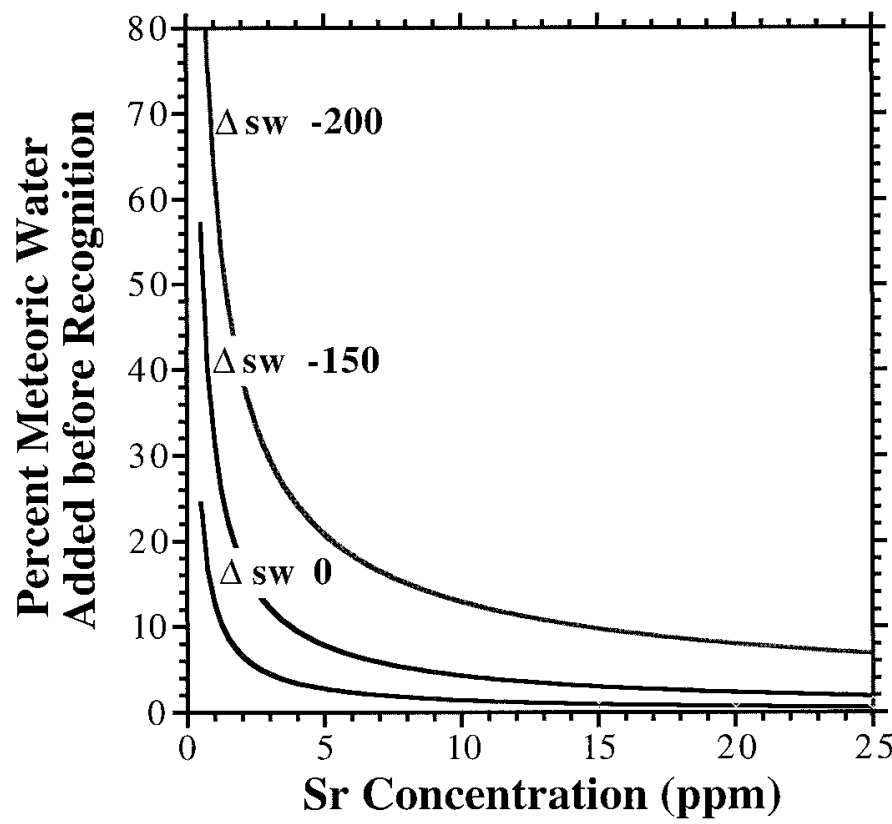

FIG. 11.-Mixing diagram showing the percent of meteoric water of various concentrations and isotopic values that could be mixed with lower Ochoan (Castile) seawater (Sr concentration, $8 \mathrm{ppm} ; \Delta \mathrm{sw},-225.0$ (0.706923)) without its presence being recognized in the strontium-isotope determinations. At a strontium concentration of $6 \mathrm{ppm}$ and a $\Delta \mathrm{sw}$ of $-150(0.707673)$, for example, meteoric ground water could form $7 \%$ of a seawater base without being detectable from an isotopic measurement of anhydrite that originated from the resulting hybrid brine

dard deviation of 218 ppm and a range of 1950-3000 ppm (Dean 1967, his appendix VIA). From a homogeneous brine at a given temperature, the amount of strontium entering an anhydrite depends on the value of the partition coefficient (e.g., Dean 1978). Using the partition coefficient of $\mathrm{Sr}^{2+}$ with respect to anhydrite, Butler (1973) estimated the $\mathrm{Sr}^{2+} / \mathrm{Ca}^{2+}$ in the original brine to have been $2.3 \times 10^{-2}$, with a range of $1.8-2.8 \times$ $10^{-2}$. In the United Arab Emirates, modern marine supratidal brines saturated with gypsum and anhydrite, which like the Castile sulfates are unassociated with dolomitization, have a $\mathrm{Sr}^{2+} / \mathrm{Ca}^{2+}$ of about $2.2 \times 10^{-2}$ (Butler 1973). This remarkably close agreement between the $\mathrm{Sr}^{2+} / \mathrm{Ca}^{2+}$ of the $\mathrm{CaSO}_{4}$-saturated marine brine of the United Arab Emirates and that calculated for the Castile brine supports a marine origin for the parent brine of the Castile evaporites.

The first few laminae of calcite at the base of the Castile contain fossils of the radiolarian genus Copicyntra (Anderson et al. 1972, their fig. 3C; Magaritz et al. 1983; Nazarov and Ormiston 1985). Because Radiolaria are strictly marine, the surface water at inception of the Castile evaporites must have been marine.

Castile couplets of anhydrite-calcite (varves) maintain nearly the same thickness over many kilometers (Dean 1967, his figs. 21 and 22; Anderson et al. 1972, their fig. 11; Dean and Anderson 1982, their fig. 3), which supports chemical homogeneity of the basinal brine, a condition much easier to attain with a dominantly marine source. The general uniformity of individual varve thickness is shown over a distance of $24 \mathrm{~km}$ by Figure 12 and, where the varves are undeformed, over a distance of $113 \mathrm{~km}$ by Figure 10 .

Leslie et al. (1997) investigated geochemical variations of six correlative laminae in 17 cores from the Anhydrite I Member. From their trace-element and isotopic ( $\mathrm{S}, \mathrm{C}$, and $\mathrm{O}$ ) data they conclude that "water depths must have been sufficient to assimilate minor inputs of continental-derived waters without showing significant changes in chemistry" and, importantly,

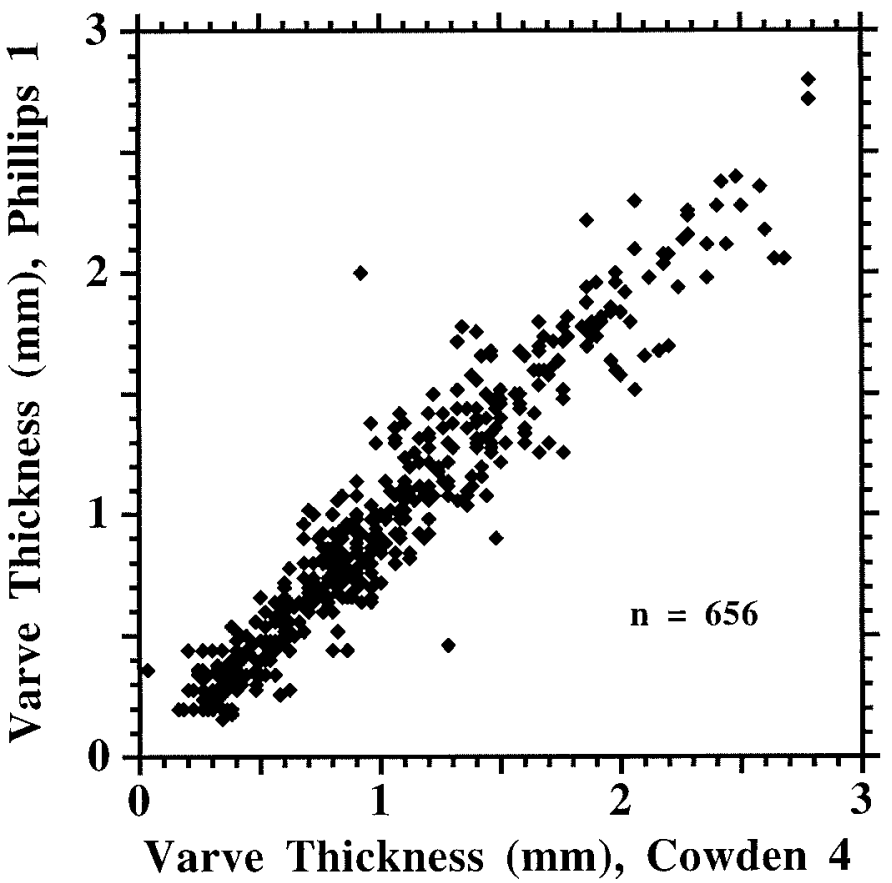

FIG. 12.-Thickness of individual varves in the UNM-Phillips core versus thickness of individual varves in the UNM-Cowden 4 core, Anhydrite I Member, showing the general uniformity of varve thicknesses over $24 \mathrm{~km}$ (data from Dean 1967, his appendix II)

that there was no "... significant input of meteoric, continental-derived waters".

\section{REINTERPRETATION OF BROMIDE DATA}

The data and arguments presented above are consistent with a Castile brine consisting of concentrated marine water and with Castile evaporitic sediments that are primary. Explanations for low bromide values of Castile halite are not in accord with these conclusions, but have called for a brine composed largely of concentrated meteoric water containing salts recycled from preexisting evaporites. The possibility that the low bromide values resulted during recrystallization of the halite (e.g., Hardie 1984) has received scant consideration.

The first halite to precipitate from concentrated modern seawater has a bromide concentration of about 75 ppm (Holser 1966; Kühn 1968). Then, as salinity increases further through the halite saturation field, the concentration of bromide increases progressively, reaching a value of nearly 200 ppm at precipitation of first bitterns (Holser 1979b). Because the concentration of bromide in seawater has not changed significantly during the Phanerozoic (Horita et al. 1991), this approximate range (75-200 ppm) holds for halite precipitated from Late Permian seawater.

Holser (1966) made the first bromide analyses of Castile halite on cuttings from the Sotex 1 Allen and Sotex 1 Link wells in Loving County, Texas, near the PDB-03 borehole (Fig. 6). Values ranged from 15 to 60 ppm. Holser (1979b, his fig. 11) reported on additional bromide values from cores from the Union 4 University 37 borehole (Fig. 6). For these cores, the profiles of bromide concentration in all three Castile halite members on a sampling scale of $30 \mathrm{~cm}$ are "very smooth, with trends in the range of 25-45 ppm over $30 \mathrm{~m}$ or more" (Holser and Anderson 1970). Hovorka (1990) analyzed core samples of Castile halite from the Gulf Research PDB-03 borehole (Fig. 6). Two samples from the Halite I Member have bromide values of 88 and $89 \mathrm{ppm}$. Seven samples from the Halite III Member range from 35 to $60 \mathrm{ppm}$ with a mean of $52 \mathrm{ppm}$. Also, 35 
samples of halite from halite beds of the Anhydrite IV Member have a "generally low Br content (20-60 ppm) with some scattered high values" (Hovorka 1990, p. 285) (range 28-142 ppm; mode 45 ppm). Because the bromide values for Castile halite samples are usually much less than 75 ppm, Anderson and Dean (1995) concluded that the Castile halite beds "... were derived from recycled salts and meteoric inflow".

The first halite to precipitate by concentrating a brine that formed by dissolving modern marine halite in meteoric water would have a bromide concentration of less than 15 ppm (see Holser 1979b). Samples of Castile halite all have bromide values greater than 15 ppm. Hovorka (1990, p. 295) concluded, therefore, that, "The $\mathrm{Br}$ concentration ... is not low enough to be wholly derived from recycling, so some concentration of marine water has occurred". On the basis of the bromide analyses, Hovorka (1990, p. 295) concluded that "... significant volumes of older halite have been recycled". Because the original volume of the Castile halite was about $5,000 \mathrm{~km}^{3}$, the fraction of supposedly recycled halite would have been large (hundreds of cubic kilometers). No evidence of recycled halite is present in our strontium-isotope data for anhydrite laminae intercalated within halite (Table 1), which have ratios identical with strontium in early Ochoan ocean water. The low values of bromide in the Castile halite samples are probably not a consequence of recycling, but a consequence of diagenesis.

Centimeter-size pseudomorphs of bottom-grown gypsum crystals occur sporadically in the upper part of Castile millennial cycles (Fig. 5B) (Kendall and Harwood 1988, 1989; Hovorka 1989, 1990; Leslie et al. 1996). Although sparse, the pseudomorphs are laterally persistent, stratigraphically restricted, and associated with, and completely transitional into, nodular anhydrite (Kendall and Harwood 1989). These characteristics led Kendall and Harwood (1989) to suggest that intervals of Castile nodular anhydrite, like many nodular anhydrite beds elsewhere (e.g., Schreiber et al. 1982; Loucks and Longman 1982; Shearman 1983), consisted originally of bottom-grown gypsum crystals that covered the floor of the evaporite basin. The nodular fabric in the Castile is especially well developed below halite intervals (Fig. 5B).

Late in the development of millennial cycles, the maximum salinity generally attained by the surface brine was the same or nearly the same as the salinity of the bottom brine. During this stage, the Castile brine body overturned, that is, the drag of wind on its vast surface area caused the brine body to circulate internally. Oxygen, at low concentration, was transported into the bottom brine. Both the surface brines and the bottom brines were supersaturated with $\mathrm{CaSO}_{4} \cdot 2 \mathrm{H}_{2} \mathrm{O}$, at low concentration, and were nearly saturated with $\mathrm{NaCl}$. While gypsum was precipitating at the surface of the brine and within the brine column, gypsum crusts formed on the basin floor. The crusts grew rapidly as new brine was persistently brought into contact with the multitude of gypsum crystal faces.

The temperature of the surface brine in its Late Permian equatorial setting was unusually high and, importantly, displayed little seasonal variation. Because of the absence of brine stratification, the temperature of the bottom brine was probably about the same as the temperature of the surface brine. The brine in contact with the gypsum crust probably had a temperature that was always greater than $18^{\circ} \mathrm{C}$. In a brine derived from seawater in which $\mathrm{NaCl}$ is saturated, gypsum dehydrates to anhydrite at temperatures $>18^{\circ} \mathrm{C}$ (Hardie 1967; Holser 1979a, his fig. 13). While settling through hundreds of meters of warm $\left(>18^{\circ} \mathrm{C}\right)$, nearly $\mathrm{NaCl}$-saturated Castile brine and while lying on the basin floor, the small crystals of cumulate gypsum dehydrated, because of their large ratio of surface area to volume (see Langbein 1979). On the other hand, the bottom-grown gypsum crystals, which were many orders of magnitude larger than the cumulate crystals, resisted dehydration because of their relatively small ratio of surface area to volume. Before their dehydration was well underway, the fields of bottom-grown gypsum crystals became buried beneath rapidly accumulating halite. During the shallow burial the interstitial brine, warm and saturated with $\mathrm{NaCl}$, provided an environment in which the gypsum crystals slowly dehydrated.
For every unit volume of gypsum converted to anhydrite, about half a unit volume of "fresh" (bromide-free) water was generated. Also, the products of the dehydration - water and anhydrite- had a volume about $10 \%$ greater than the original gypsum. In the Castile sediments, water generated during the dehydration (during formation of nodular anhydrite) would have been forced upward through the halite by the hydraulic pressure resulting from the increase in volume, by the compaction pressure resulting from the load of the halite, and by the buoyancy pressure of the water of dehydration. This upward movement of water occurred shortly after deposition, while the halite was permeable. As it was forced upward, the bromide-free, "fresh" water resulted in recrystallization of the halite, and a fraction of the bromide within the halite was expelled, and was transferred into the overlying brine body. Low concentrations of bromine in halite beds of the Stassfurt Series (Upper Permian, Zechstein Formation) have been explained by a similar mechanism (Kühn 1966).

\section{CASTILE DEPOSITIONAL MODEL}

The closed-basin drawdown models for the Castile (Fig. 7) were developed without having the evidence that the Castile brine had a marine origin. Using this understanding, we have formulated a modified model, the "closed-basin, deep-marine-brine model" (Fig. 13).

The immense volume of water lost annually from the basin by evaporation was mainly replaced by seawater that entered the basin along its southern and possibly southwestern margin (Fig. 13). If this influx had been through a channel, it would have to have had a very small cross-sectional area (Lucia 1972; Kinsman 1974; Kendall 1988). The size and shape of such a small channel could not have been maintained for long (see Kendall 1988), and, therefore, the volume of influxing seawater could not have been regular. Yet, the regular thickness of varves that characterize much of the Castile and that are correlatable over the entire basin suggests that influx was persistent and that its volume was about the same each year over thousands of years. A long-lasting strait between the Permian ocean and the Castile basin did not exist; rather, the Castile basin, though much of its history at least, was completely disconnected from the Permian ocean (Lucia 1972; Kendall and Harwood 1989; Anderson and Dean 1995).

To replace the water lost by evaporation, most seawater probably entered the basin as seepage through the Capitan Formation (Fig. 13). The Capitan reef probably had insufficient permeability to allow annual passage of tens of cubic kilometers of seawater, but the Capitan forereef talus, which constitutes about three-fourths of the formation, was coarse and rubble-dominated, and probably provided the conduit for influx of seawater (A.A. Brown, personal communication, 1998). Near the end of the Guadalupian, the channel (or channels) that had been in existence throughout the Guadalupian may have become filled with reef debris. Indeed, the filling of these channels may have initiated Ochoan evaporite conditions.

Reflux of highly concentrated brine was directly through reef and forereef deposits around the entire circumference of the basin. Where steeply dipping, the reef and forereef rocks were incompletely covered by evaporites, allowing infiltration of the dense brine. Much of the refluxing brine eventually discharged into the ocean.

The usual level of the Castile brine surface may have been only slightly less than sea level. To compensate for a falling brine surface, a persistent current of seawater seeped into the basin. The rate of marine inflow may usually have been sufficient to prevent significant drawdown, and during much of Castile sedimentation the brine body may have been hundreds of meters deep.

\section{SUMMARY AND CONCLUSIONS}

A stratigraphic array of 36 samples of Castile anhydrite has a mean $\delta^{34} \mathrm{~S}$ of $11.6 \%$ with little variance. These $\delta^{34} \mathrm{~S}$ values fall within the range of sulfur within sulfate of Permian seawater, indicating that the sulfate in the 


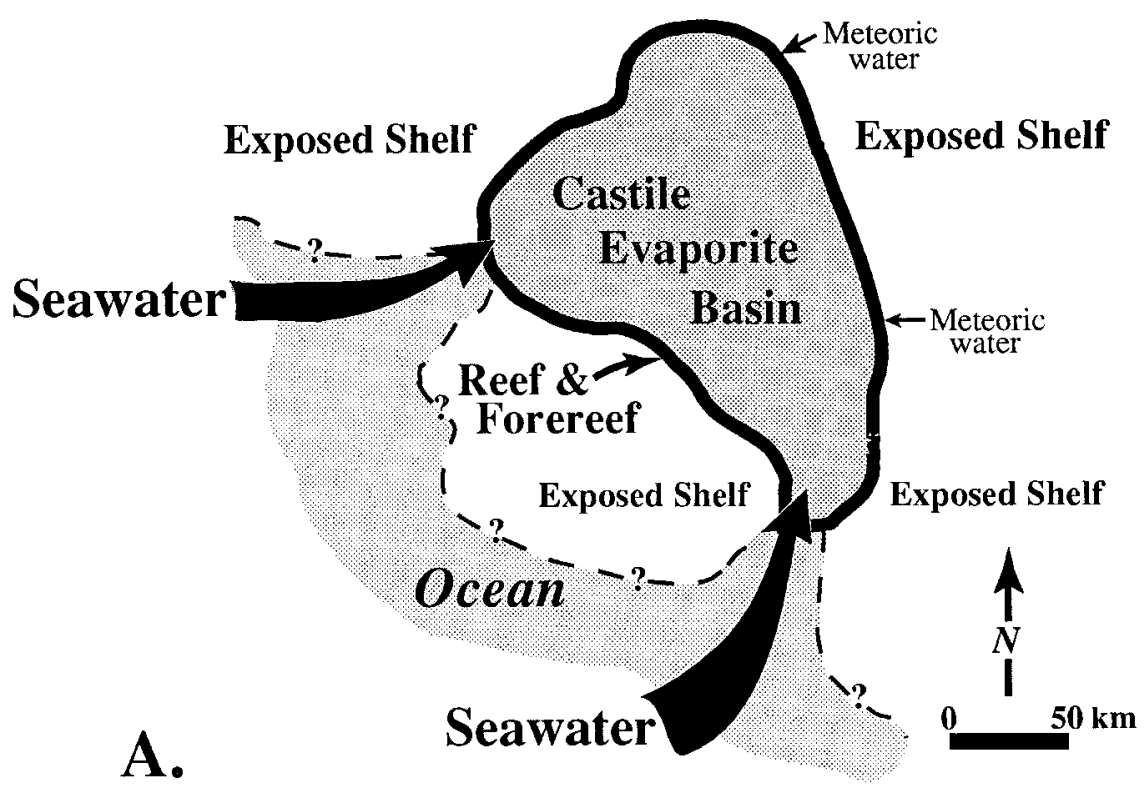

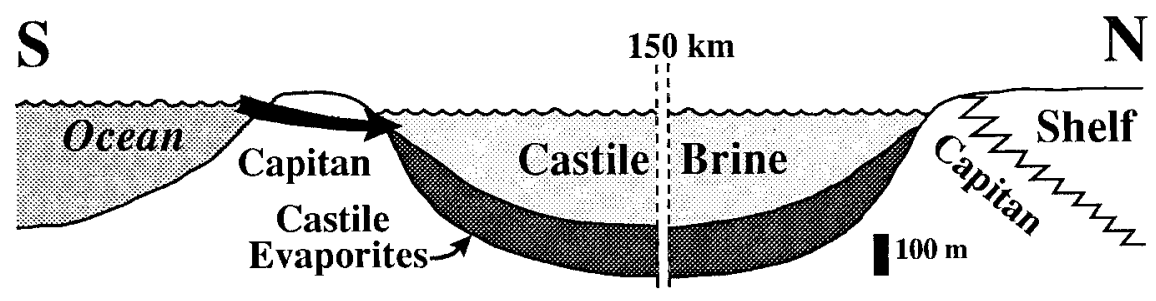

B.
FIG. 13.-Closed-basin, deep-marine-brine model for the Castile evaporites. A) Seawater entered the basin chiefly by seepage along one or more segments of the reef front. These seepage areas were possibly the location of the channels through which seawater had entered the Delaware Basin during Guadalupian time. B) Highly diagrammatic cross section suggesting that inflow of seawater, which probably occurred chiefly through the forereef talus of the Capitan Formation, may have generally been able to replace water lost by evaporation without substantial drawdown (cf. Fig. 8).
Castile anhydrite was derived from Permian seawater. Both the Tansill and the Capitan formations show evidence of erosion during the nearly 200,000 yr of Castile time. Conceivably, ground water and surface water dissolved some shelfal strata of gypsum and anhydrite and transported the solutes into the Castile depositional basin. The sulfur-isotope data, however, are also consistent with derivation of the Castile sulfate exclusively from early Ochoan seawater.

Fifty-nine of 65 samples of Castile calcite, anhydrite, and gypsum, from an array of stratigraphic and geographic locations, have an ${ }^{87} \mathrm{Sr} /{ }^{86} \mathrm{Sr}$ ratio, within error, of 0.706923 ( $\Delta$ sw of -225.0$)$. This value is the same as the ${ }^{87} \mathrm{Sr} /{ }^{86} \mathrm{Sr}$ ratio of seawater during Castile (early Ochoan) time. This coincidence shows that the Castile brine was derived dominantly from early Ochoan seawater. If the Castile brine had received significant influxes of meteoric water, the $\Delta \mathrm{sw}$ values would have been, at least intermittently, significantly larger than -225 (0.706923). The remarkable consistency of the ${ }^{87} \mathrm{Sr} /{ }^{86} \mathrm{Sr}$ values also dictates that the parent brine consisted dominantly of marine water. Only the huge, homogeneous reservoir of strontium in the oceans could have caused such a consistent isotopic signal.

Low values of bromide in samples of Castile halite, which have been used to support a major contribution of meteoric water, probably resulted from diagenesis. The values generally range from 20 to $40 \mathrm{ppm}$ compared to bromide values of 75 to $200 \mathrm{ppm}$ for halite precipitated from marinederived brine. During their shallow burial by halite, centimeter-size, bottom-grown crystals of gypsum were immersed in a warm $\left(>18^{\circ} \mathrm{C}\right), \mathrm{NaCl}-$ saturated interstitial brine. These crystals were slowly transformed diagenetically into anhydrite usually with a nodular fabric. For every unit volume of gypsum that dehydrated to anhydrite, half a unit of "fresh", bromidefree water of crystallization was expelled. This water, forced upward through the still permeable halite (and anhydrite), resulted in recrystallization of halite and in removal of some of its original marine bromide.

By analogy with modern evaporitic environments, a conservative estimate for the rate of evaporation from the Late Permian (Ochoan) Castile brine body is $2 \mathrm{~m} / \mathrm{yr}$. The brine body had a surface area of at least 25,900 $\mathrm{km}^{2}$. On the basis of these values, at least $52 \mathrm{~km}^{3}$ of water were evaporated annually, yet the Castile brine body never dried up. The average volume lost annually from the basin by evaporation approximated the average total volume of marine water and meteoric ground water introduced annually. A hot, generally dry, flat shelf could probably not have supplied a significant fraction of the total annual influx as spring water for many tens of thousands of years. Both the isotopic and geologic evidence are consistent with Castile evaporites that precipitated from a parent brine formed of concentrated Late Permian (Ochoan) seawater.

The Castile evaporite basin was disconnected from the Permian ocean. Marine ground water flowed through the Capitan Formation into the evaporite basin along its southern and possibly western margins. The rate of inflow may have usually been great enough to replace water lost by evaporation. Thus, drawdown of the brine surface would have generally been 
minor, and the brine level would usually not have been much lower than sea level.

\section{ACKNOWLEDGMENTS}

We thank Sibylle U. Noé for showing one of us field evidence for karstification at the top of the Tansill Formation, and Paul M. Harris for bringing our attention to an important reference. We thank Brenda L. Kirkland for stimulating conversations on the geology of the Capitan and Castile Formations, and Peggy L. Kirkland for her help in collecting and photographing Castile core samples and in editing the manuscript. We also thank Jay L. Banner, Kathleen C. Benison, and B. Charlotte Schreiber for their thoughtful reviews. The many contributions of Roger Y. Anderson to the geology of the Castile Formation have provided the foundation for almost all studies on the Castile that followed, including this one. He passed his enthusiasm for the Castile on to his students, and he is indirectly responsible for launching the effort on this present work. We acknowledge his tutelage, and especially his lessons on how to solve geologic problems. He has been and remains an inspirational teacher.

The data described in this paper have been archived, and are available in digital form, at the World Data Center-A for Marine Geology and Geophysics, NOAA/ NGDC, 325 Broadway, Boulder, CO 80303; (phone 303-497-6339; fax 303-4976513; E-mail: wdcamgg@ngdc.noaa.gov; URL http://www.ngdc.noaa.gov/mgg/ sepm/jrs/

\section{REFERENCES}

Adams, J.E., 1944, Upper Permian Ochoan series of Delaware Basin, west Texas and southeastern New Mexico: American Association of Petroleum Geologists, Bulletin, v. 28, p. $1592-1625$

Adams, J.E., And Frenzel, H.N., 1950, Capitan barrier reef, Texas and New Mexico: Journal of Geology, v. 58, p. 289-312.

Adams, J.E., Cheney, M.G., DeFord, R.K., Dickey, R.I., Dunbar, C.O., Hills, J.M., King, R.E., Lloyd, E.R., Miller, A.K., and Needham, C.E.., 1939, Standard Permian section of North America: American Association of Petroleum Geologists, Bulletin, v. 23, p. 1673-1681.

Anderson, R.Y., 1981, Deep-seated salt dissolution in the Delaware Basin: New Mexico Geological Society, Special Publication 10, p. 133-145.

ANDERSON, R.Y., 1982, Long geoclimatic record from the Permian: Journal of Geophysical Research, v. 87, p. 7285-7294.

Anderson, R.Y., 1993, The Castile as a "nonmarine", evaporite, in Love, D.W., Hawley, J.W., Kues, B.S., Adams, J.W., Austin, G.S., and Barker, J.M., eds., Carlsbad Region, New Mexico and West Texas: New Mexico Geological Society, Guidebook, Forty-Fourth Annual Field Conference, p. 12-13.

Anderson, R.Y., and Dean, W.E., 1995, Filling the Delaware Basin: Hydrologic and climatic controls on the Upper Permian Castile Formation varved evaporite, in Scholle, P.A., Peryt, T.M., and Ulmer-Scholle, D.S., eds., The Permian of Northern Pangea: Sedimentary Basins and Economic Resources, v. 1: New York, Springer-Verlag, p. 61-78.

ANDERSON, R.Y., AND KIRKLAND, D.W., 1966, Intrabasin varve correlation: Geological Society of America, Bulletin, v. 77, p. 241-255.

Anderson, R.Y., Dean, W.E., Kirkland, D.W., and Snider, H.I., 1972, Permian Castile varved evaporite sequence, West Texas and New Mexico: Geological Society of America, Bulletin, v. 77 , p. $241-256$.

B Авсоск, L.C., 1977, Life in the Delaware Basin: The paleoecology of the Lamar Limestone, in Hileman, M.E., and Mazzullo S.J., eds., Upper Guadalupian Facies Permian Reef Complex, Guadalupe Mountains, New Mexico and West Texas: Society of Economic Paleontologists and Mineralogists, Permian Basin Section, Publication 77-16, 1977 Field Conference Guidebook, p. 357-387.

BAKER, C.L., 1929, Depositional history of the redbeds and saline residues of the Texas Permian: University of Texas, Bulletin 2901, p. 9-65.

Banner, J.L., Musgrove, M., and Capro, R.C., 1994, Tracing ground-water evolution in a limestone aquifer using $\mathrm{Sr}$ isotopes: Effects of multiple sources of dissolved ions and mineral-solution reactions: Geology, v. 22, p. 687-690.

Brookins, D.G., 1988, Seawater ${ }^{87} \mathrm{Sr} /{ }^{86} \mathrm{Sr}$ for the Late Permian Delaware Basin evaporites (New Mexico, USA): Chemical Geology, v. 69, p. 209-214.

Byrant, J.D., Jones, D.S., And Mueller, P.A., 1995, Influence of freshwater flux on ${ }^{87} \mathrm{Sr} /{ }^{86} \mathrm{Sr}$ chronostratigraphy in marginal marine environments and dating of vertebrate and invertebrate faunas: Journal of Paleontology, v. 69, p. 1-6.

BuRdetT, J.W., 1985, Stable carbon and oxygen isotopes and organic carbon, carbonate, and anhydrite accumulation rate records through laminated evaporite cycles, Permian Castile Formation, Delaware Basin, Texas and New Mexico [unpublished M.S. thesis]: University of South Carolina, Chapel Hill, South Carolina, 86 p. (plus an appendix of 82 p.).

ButLer, G.P., 1973, Strontium geochemistry of modern and ancient calcium sulfate minerals, in Purser, B.H., ed., The Persian Gulf: Holocene Carbonate Sedimentation and Diagenesis in a Shallow Epicontinental Sea: New York, Springer-Verlag, p. 423-452

Claypool, G.E., Holser, W.T., Kaplan, I.R., Sakai, H., and ZaK, I., 1980, The age curves of sulfur and oxygen isotopes in marine sulfate and their mutual interpretation: Chemical Geology, v. 28, p. 199-260.

Crowley, T.J., Hyde, W.T., And Short, D.A., 1989, Seasonal cycle variations on the supercontinent of Pangaea: Geology, v. 17, p. 457-460.
Dean, W.E., 1967, Petrology and geochemical variations in the Permian Castile varved anhydrite, Delaware Basin, Texas and New Mexico [unpublished Ph.D. thesis]: University of New Mexico, Albuquerque, New Mexico, 326 p.

DEAn, W.E., 1978, Some uses of stable isotopes of carbon, oxygen, and sulfur in solving problems related to evaporite deposits, in Dean, W.E., and Schreiber, B.C., eds., Notes for a Short Course on Marine Evaporites: Society of Economic Paleontologists and Mineralogists, Short Course 4, p. 125-145.

Dean, W.E., AND Anderson, R.Y., 1978, Salinity cycles: Evidence for subaqueous deposition of Castile Formation and lower part of Salado Formation, Delaware Basin, Texas and New Mexico, in Austin, G.S., compiler, Geology and Mineral Deposits of Ochoan Rocks in Delaware Basin and Adjacent Areas: New Mexico Bureau of Mines and Mineral Resources, Circular 159 , p. 15-31.

Dean, W.E., And Anderson, R.Y., 1982, Continuous subaqueous deposition of the Permian Castile Evaporites, Delaware Basin, Texas and New Mexico, in Handford, C.R., Loucks, R.G., and Davies, G.R., eds., Depositional and Diagenetic Spectra of Evaporites-A Core Workshop: Society of Economic Paleontologists and Mineralogists, Core Workshop 3, p. 324-353.

Denison, R.E., Koepnick, R.B., Burke, W.H., Hetherington, E.A., and Fletcher, A., 1994a, Construction of the Mississippian, Pennsylvanian and Permian seawater ${ }^{87} \mathrm{Sr} /{ }^{86} \mathrm{Sr}$ curve: Chemical Geology (Isotope Geoscience Section), v. 112, p. 145-167.

Denison, R.E., Koepnick, R.B., Fletcher, A., Howell, M.W., and Callaway, W.S., 1994b, Criteria for the retention of original seawater ${ }^{87} \mathrm{Sr} /{ }^{86} \mathrm{Sr}$ in ancient shelf limestones: Chemical Geology (Isotope Geoscience Section), v. 112, p. 131-143.

Denison, R.E., KirkLand, D.W., and Evans, R., 1998, Using strontium isotopes to determine the age and origin of gypsum and anhydrite beds: Journal of Geology, v. 106, p. 1-17.

ForNey, G.G., 1975, Permo-Triassic sea-level change: Journal of Geology, v. 83, p. 773-779. GAo, G., 1990, Geochemical and isotopic constraints on the diagenetic history of a massive stratal, Late Cambrian (Royer) dolomite, lower Arbuckle Group, Slick Hills, SW Oklahoma, USA: Geochimica et Cosmochimica Acta, v. 54, p. 1929-1989.

Garber, R.A., Grover, G.A., And Harris, P.M., 1989, Geology of the Capitan shelf marginsubsurface data from the northern Delaware Basin, in Harris, P.M., and Grover, G.A., eds., Subsurface and Outcrop Examination of the Capitan Shelf Margin, Northern Delaware Basin: SEPM, Core Workshop 13, p. 3-269.

GolonKa, J., Ross, M.I., And ScOTESE, C.R., 1994, Phanerozoic paleogeographic and paleoclimatic modeling maps, in Embry, A.F., Beauchamp, B., and Glass, D.J., eds., Pangea: Global Environments and Resources: Canadian Society of Petroleum Geologists, Memoir 17, p. 147.

HARDIE, L.A., 1967, The gypsum-anhydrite equilibrium at 1 atmosphere pressure: American Mineralogist, v. 52, p. 171-200.

HARDIE, L.A., 1984, Evaporites: Marine or non-marine?: American Journal of Science, v. 284, p. $193-240$.

Hitl, C.A., 1996, Geology of the Delaware Basin, Guadalupe, Apache, and Glass Mountains, New Mexico and west Texas: SEPM, Permian Basin Section, Publication 96-39, 480 p.

Hitl, C.A., 1999, Reevaluation of the Hovey Channel in the Delaware Basin, west Texas: American Association of Petroleum Geologists, Bulletin, v. 83, p. 277-294.

HolLand, H.D., 1972, The geological history of sea water-an attempt to solve the problem: Geochimica et Cosmochimica Acta, v. 36, p. 637-652.

Holser, W.T., 1966, Bromide geochemistry of salt rocks, in Rau, J.L., ed., Second Symposium on Salt: Cleveland, Ohio, Northern Ohio Geological Society, v. 1, p. 248-275.

HoLser, W.T., 1979a, Mineralogy of evaporites, in Burns, R.G., ed., Marine Minerals: Mineral Society of America, Short Course Notes, v. 6, p. 211-293.

Holser, W.T., 1979b, Trace elements and isotopes in evaporites, in Burns, R.G., ed., Marine Minerals: Mineral Society of America, Short Course Notes, v. 6, p. 295-346.

Holser, W.T., and Anderson, R.Y., 1970, Bromide distribution in Castile halites, Delaware Basin (abstract): Annual Joint Geological Society of America and Allied Societies Meeting, Abstracts with Program, v. 2, p. 580.

Holser, W.T., and KaPLAN, I.R., 1966, Isotope geochemistry of sedimentary sulfates: Chemical Geology, v. 1, p. 93-135.

Horita, J., Friedman, T.J., Lazar, B., and Holland, H.D., 1991, The composition of Permian seawater: Geochimica et Cosmochimica Acta, v. 55, p. 417-432.

Hovorka, S.D., 1989, Depth evolution of the Delaware Basin-Castile/Salado transition, in Harris, P.M., and Grover, G.A., eds., Subsurface and Outcrop Examination of the Capitan Shelf Margin, Northern Delaware Basin: SEPM, Core Workshop 13, p. 441-450.

Hovorka, S.D., 1990, Sedimentary processes controlling halite deposition, Permian Basin, Texas [unpublished Ph.D. thesis]: University of Texas-Austin, Austin, Texas, 393 p.

Jones, C.E., Jenkyns, H.C., And Hesselbo, S.P., 1994, Strontium isotopes in Early Jurassic seawater: Geochimica et Cosmochimica Acta, v. 58, p. 1285-1301.

Kendall, A.C., 1984, Evaporites, in Walker, R.G., ed., Facies Models, 2nd Edition: Geoscience Canada, Reprint Series 1, p. 259-296.

Kendall, A.C., 1988, Aspects of evaporite basin stratigraphy, in Schreiber, B.C., ed., Evaporites and Hydrocarbons: New York, Columbia University Press, p. 11-65.

Kendall, A.C., ANd Harwood, G.M., 1988, Shallow-water gypsum in the Castile evaporitesSignificance and implications (abstract): International Association of Sedimentologists, 9th Regional Meeting of Sedimentology, Leuven, Belgium, p. 110.

Kendall, A.C., and Harwood, G.M., 1989, Shallow water gypsum in Castile FormationSignificance and implications, in Harris, P.M., and Grover, G.A., eds., Subsurface and Outcrop Examination of the Capitan Shelf Margin, Northern Delaware Basin: SEPM, Core Workshop 13, p. 451-457.

King, R.H., 1947, Sedimentation in the Permian Castile sea: American Association of Petroleum Geologists, Bulletin, v. 31, p. 470-477.

Kinsman, D.J.J., 1974, Evaporite deposits of continental margins, in Coogan, A.H., Fourth 
Symposium on Salt, vol. 1: Cleveland, Ohio, Northern Ohio Geological Society, p. 255 259.

Kirkland, B.L., Longacre, S.A., And Stoudt, E.L., 1993, Reef, in Bebout, D.G., and Kerans, C., eds., Guide to the Permian Reef Geology Trail, McKittrick Canyon, Guadalupe Mountains National Park, West Texas: University of Texas at Austin, Bureau of Economic Geology, Guidebook 26, 48 p.

KirkLAND, D.W., AND ANDERSON, R.Y., 1970, Microfolding in the Castile and Todilto evaporites, Texas and New Mexico: Geological Society of America, Bulletin, v. 81, p. 3259-3282.

KüHN, R., 1968, Geochemistry of the German Potash deposits, in Mattox, R.B., ed., Saline Deposits; A Symposium Based on Papers from the International Conference on Saline Deposits, New York: Geological Society of America, Special Paper 88, 427-504.

KushNIR, J., 1981, Formation and early diagenesis of varved evaporite sediments in a coastal hypersaline pool: Journal of Sedimentary Petrology, v. 51, p. 1193-1203.

Kutzbach, J.E., and Gallimore, R.G., 1989, Pangaean climates: Megamonsoons of the megacontinent: Journal of Geophysical Research., v. 94, p. 3341-3357.

Langbein, R., 1979, Petrologische Aspekte der Anhydritbildung: Zeitschrift für Geologische Wissenschaften, v. 7, p. 913-926.

Leslie, A.B., Kendall, A.C., Harwood, G.M., and Powers, D.W., 1996, Conflicting indicators of paleodepth during deposition of the Upper Permian Castile Formation, Texas and New Mexico, in Kemp, A.E.S., ed., Palaeoclimatology and Palaeooceanography from Laminated Sediments: Geological Society of London, Special Publication 116, p. 79-92.

Leslie, A.B., Harwood, G.M., and Kendall, A.C., 1997, Geochemical variations within a laminated evaporite deposit: Evidence for brine composition during formation of the Permian Castile Formation, Texas and New Mexico, USA: Sedimentary Geology, v. 110, p. 223 235.

Loucks, R.G., And Longman, M.W., 1982, Lower Cretaceous Ferry Lake Anhydrite, Fairway Field, East Texas: Product of shallow-subtidal deposition, Society of Economic Paleontologists and Mineralogists, Core Workshop 3, p. 130-173.

Lowenstein, T.K., 1988, Origin of depositional cycles in the Permian "saline giant": The Salado (McNutt zone) evaporites of New Mexico and Texas: Geological Society of America, Bulletin, v. 100, p. 592-608.

Lucia, F.J., 1972, Recognition of evaporite-carbonate shoreline sedimentation, in Rigby, J.K., and Hamblin, W.K., eds., Recognition of Ancient Sedimentary Environments: Society of Economic Paleontologists and Mineralogists,, Special Publication 16, p. 160-191.

Magaritz, M., 1987, A new explanation for cyclic deposition in marine evaporite basins: Meteoric water input: Chemical Geology, v. 62, p. 239-250.

Magaritz, M., Anderson, R.Y., Holser, W.T., Saltzman, E.S., and Garber, J., 1983, Isotope shifts in the Late Permian of the Delaware Basin, Texas, precisely timed by varved sediments: Earth and Planetary Science Letters, v. 66, p. 111-124.

MAIKLEM, W.R., 1971, Evaporative drawdown-A mechanism for water-level lowering and diagenesis in the Elk Point Basin: Bulletin of Canadian Petroleum Geology, v. 19, p. 487503.

McArthur, J.M., 1995, Recent trends in Sr isotope stratigraphy: Terra Nova, v. 6, p. 331358.

Melim, L.A., 1991, The origin of dolomite in the Permian (Guadalupian) Capitan Formation, Delaware Basin, West Texas and New Mexico: Implications for dolomitization models [unpublished Ph.D. thesis]: Southern Methodist University, Dallas, Texas, $200 \mathrm{p}$.

Melim, L.A., And Scholle, P.A., 1989, Dolomitization model for the forereef facies of the Permian Capitan Formation, Guadalupe Mountains, Texas-New Mexico, in Harris, P.M. and Grover, G.A., eds., Subsurface and Outcrop Examination of the Capitan Shelf Margin, Northern Delaware Basin, SEPM, Core Workshop 13, p. 407-413.

Mitchell, J.M., JR., 1976, An overview of climatic variability and its causal mechanisms: Quaternary Research, v. 6, p. 481-493.

NaZARov, B.B., AND Ormiston, A.R., 1985, Radiolaria from the Late Paleozoic of the southern Urals, USSR and west Texas, USA: Micropaleontology, v. 31, p. 1-54.

Newell, N.D., Rigby, J.K., Fischer, A.G., Whiteman, A.J., Hickox, J.E., and Bradley, J.S., 1953, The Permian Reef Complex of the Guadalupe Mountains region, Texas and New Mexico: San Francisco, W.H. Freeman, 236 p.

Oriel, S.S., Myers, D.A., And Crosby, E.J., 1967, West Texas Permian Basin region-Paleo- tectonic investigations of the Permian System in the United States: U.S. Geological Survey, Professional Paper 515-C, p. C17-C60.

Palmer, M.R., And Edmond, J.M., 1992, Controls over the strontium isotope composition of river water: Geochimica et Cosmochimica Acta, v. 56, p. 2099-2111

Parrish, J.M., Parrish, J.T., and Ziegler, A.M., 1986, Permian-Triassic paleogeography and paleoclimatology and implications for therapsid distribution, in Hotton, N., III, MacLean, P.D., Roth, J.J., and Roth, E.C., eds., The Ecology and Biology of Mammal-like Reptiles: Washington, D.C., Smithsonian Institution Press, p. 109-131.

Parrish, J.T., 1995, Geologic evidence of Permian climate, in Scholle, P.A., Peryt, T.M., and Ulmer-Scholle, D.S., eds., The Permian of Northern Pangea: Sedimentary Basins and Economic Resources, vol. 2: New York, Springer-Verlag, p. 53-61.

Ross, C.A., 1986, Paleozoic evolution of southern margin of Permian basin: Geological Society of America, Bulletin, v. 97, p. 536-554.

Ross, C.A., And Ross, J.R.P., 1987, Late Paleozoic sea levels and depositional sequences, in Ross, C.A., and Haman, D., eds., Timing and Depositional History of Eustatic Sequences, Constraints on Seismic Stratigraphy: Cushman Foundation for Foraminiferal Research, Special Publication 24, p. 137-149.

Scholle, P.A., Ulmer, D.S., And Melim, L.A., 1992, Late-stage calcites in the Permian Capitan Formation and its equivalents, Delaware Basin margin, west Texas and New Mexico: Evidence for replacement of precursor evaporites: Sedimentology, v. 39, p. 207-234.

SснміDт, V. 1977. Inorganic and organic reef growth and subsequent diagenesis in the Permian Capitan Reef Complex, Guadalupe Mountains, Texas, New Mexico, in Hilleman, M.E., and Mazzullo, S.J., eds., Upper Guadalupian facies, Permian reef complex, Guadalupe Mountains, New Mexico and west Texas: Midland, Texas, Society of Economic Paleontologists and Mineralogists, Permian Basin Section, Publication 77-16, 1977 Field Conference Guidebook, p. 93-132.

Schopf, T.J.M., 1980, Paleoceanography: Cambridge, Massachusetts, Harvard University Press, $341 \mathrm{p}$.

Schreiber, B.C., Roth, M.S., and Helman, M.L., 1982, Recognition of primary facies characteristics of evaporites and the differentiation of these forms from diagenetic overprints, in Handford, C.R., Loucks, R.G., and Davies, G.R., eds., Depositional and Diagenetic Spectra of Evaporites-A Core Workshop, SEPM, Core Workshop 3, p.1-33.

Scotese, C.R., 1994, Late Permian paleogeographic map, in Klein, G.D, ed., Pangea: Paleoclimate, Tectonics, and Sedimentation during Accretion, Zenith and Breakup of a Supercontinent: Geological Society of America, Special Paper 288, p. 232-242.

Shearman, D.J., 1983, Syndepositional and late diagenetic alteration of primary gypsum to anhydrite, in Schreiber, B.C., ed., Sixth International Symposium on Salt, vol. 1: Alexandria, Virginia, Salt Institute, p. 41-50

SHowers, V., 1979, World facts and figures: New York, Wiley, 757 p..

SNIDER, H.I., 1966, Stratigraphy and associated tectonics of the Upper Permian Castile-SaladoRustler evaporite complex, Delaware Basin, west Texas and southeast New Mexico [unpublished Ph.D. thesis]: University of New Mexico, Albuquerque, New Mexico, 196 p.

Timofeef, M.N., Lowenstein, T.K., BlackbuRn, W.H., And Hardie, L.A., 1998, Environmenta SEM (ESEM) x-ray EDS chemical analysis of frozen fluid inclusions: Preliminary result from aqueous standards, fluid inclusions in laboratory-grown halite crystals, and Phanerozoic halites (abstract): Seventh Meeting of the Pan-American Conference on Research on Fluid Inclusions, Las Vegas, Nevada, p. 67

Udden, J.A., 1924, Laminated anhydrite in Texas: Geological Society of America, Bulletin, v. 35 , p. $347-354$

WARD, R.F., Kendall, C.G.St.C., And HaRris, P.M., 1986, Upper Permian (Guadalupian) facies and their association with hydrocarbons-Permian Basin, west Texas and New Mexico: American Association of Petroleum Geologists, Bulletin, v. 70, p. 239-262.

Received 9 April 1999; accepted 27 September 1999.

\section{APPENDIX 1}

Strontium isotopic data for 65 samples of the Castile Formation have been archived and are available from the World Data Center-A for Marine Geology and Geophysics, NOAA/NGDC. See concluding paragraph of text for information on accessing the data. 